\title{
Ru(II) Complexes Bearing O, O-Chelated Ligands Induced Apoptosis in A549 Cells through the Mitochondrial Apoptotic Pathway
}

\author{
Jincan Chen, ${ }^{1}$ Jie Wang, ${ }^{1}$ Yuanyuan Deng, ${ }^{1}$ Tao Wang, ${ }^{2,3}$ Tifang Miao, ${ }^{4}$ Chengpeng Li, ${ }^{5}$ \\ Xianhong Cai, ${ }^{1}$ Ying Liu, ${ }^{1}$ Justin Henri, ${ }^{6}$ and Lanmei Chen $\left(\mathbb{1}^{1}\right.$ \\ ${ }^{1}$ Guangdong Key Laboratory for Research and Development of Nature Drugs, Marine Biomedical Research Institute, \\ School of Pharmacy, Guangdong Medical University, Zhanjiang 524023, China \\ ${ }^{2}$ School of Nursing, Zhengzhou University, Zhengzhou 450001, China \\ ${ }^{3}$ Centre for Molecular Medicine and Innovative Therapeutics, Murdoch University, Perth 6150, Australia \\ ${ }^{4}$ School of Chemistry and Materials Science, Huaibei Normal University, Huaibei 235000, China \\ ${ }^{5}$ The Public Service Platform of South China Sea for R\&D Marine Biomedicine Resources, Marine Biomedical Research Institute, \\ Guangdong Medical University, Zhanjiang 524023, China \\ ${ }^{6}$ School of Medicine Deakin University, Geelong, Victoria 3128, Australia
}

Correspondence should be addressed to Lanmei Chen; lanmeichen@126.com

Received 5 June 2020; Accepted 23 July 2020; Published 17 August 2020

Academic Editor: Massimiliano F. Peana

Copyright (C) 2020 Jincan Chen et al. This is an open access article distributed under the Creative Commons Attribution License, which permits unrestricted use, distribution, and reproduction in any medium, provided the original work is properly cited.

Two new $\mathrm{Ru}(\mathrm{II})$ complexes containing $\mathrm{O}$, O-chelated ligands, $\mathrm{Ru}(\mathrm{dip})_{2}(\mathrm{SA})(\mathbf{R u}-\mathbf{1})$ and $\mathrm{Ru}(\mathrm{dmp})_{2}(\mathrm{SA})(\mathbf{R u}-\mathbf{2})($ dip $=4$,7-diphenyl1,10-phenanthroline; $\mathrm{dmp}=2$,9-dimethyl-1,10-phenanthroline; $\mathrm{SA}=$ salicylate) were synthesized to evaluate their cytotoxicity in vitro. These complexes were found to exhibit moderate antitumor activity to different types of human cancers, including A549 (human lung carcinoma), MCF-7 (breast cancer), HeLa (human cervical cancer), and HepG2 (human hepatocellular carcinoma) cell lines, but displayed low toxicity to human normal cell lines BEAS-2B (immortalized human bronchial epithelial cells) when compared with that of cisplatin. Further studies revealed that these complexes could induce apoptosis in A549 cells, including activating caspase family proteins and poly (ADP-ribose) polymerase (PARP), reducing Bcl-2/Bax and Bcl-xl/Bad ratio, enhancing cellular reactive oxygen species (ROS) accumulation, triggering DNA damage, decreasing mitochondrial membrane potential (MMP), and leading cytochrome $c$ release from mitochondria. Notably, complex Ru-1 showed low toxicity to developing zebrafish embryos. The obtained results suggest that these new synthetic complexes have the potential to be developed as low-toxicity agents for lung cancer treatment.

\section{Introduction}

As a new class of nonplatinum metal complexes, rutheniumbased compounds possess valuable photophysical and photochemical properties and high structural diversity, which provide more direction for designing new ruthenium anticancer drugs $[1,2]$. More importantly, ruthenium-based complexes often show better tumor cell selectivity than platinum metal complexes, in addition to low toxicity to normal cells and multiple anticancer mechanisms, thus making them attractive chemotherapeutic agents $[3,4]$. So far, there are four ruthenium complexes with different ligands, that is, $[\mathrm{ImH}]\left[\right.$ trans- $\left.\mathrm{RuCl}_{4}(\mathrm{DMSO})(\mathrm{Im})\right]$ (NAMI-A) $[5,6],[\mathrm{IndH}]\left[\right.$ trans- $\mathrm{RuCl}_{4}(\mathrm{Ind})_{2}$ ] (KP1019) [7], KP133910 [8], and the $\mathrm{Ru}(\mathrm{II})$-based photosensitizer, TLD1433 [9, 10], have progressed to different stages in clinical trials. In the review paper, Chen et al. pointed out that the selection of ligands plays a key role in the antitumor cell selectivity, targeting, antitumor activity, and mechanism of ruthenium compounds [3].

However, while there is a large number of studies mainly focused on $\mathrm{Ru}(\mathrm{II})$ complexes containing $\mathrm{N}, \mathrm{N}-$ and $\mathrm{C}$, 
$\mathrm{N}$-chelated ligands, there is little research on the biological activities of $\mathrm{O}$, O-chelating $\mathrm{Ru}(\mathrm{II})$ complexes. de Carvalho et al. found that ruthenium complex with xanthoxylin (RCX) ligand exhibited a potent cytotoxic effect in a panel of cancer cell lines in monolayer cultures and induced S-phase arrest and caused ERK1/2-mediated apoptosis in HepG2 cells through a p53-independent pathway [11]. Habtemariam et al. reported that the water-soluble $\mathrm{Ru}(\mathrm{II})$ acetylacetonate coordination compound $([\mathrm{Ru}(\mathrm{acac})(\mathrm{pdto})] \mathrm{Cl}$, where pdto $=2,2^{\prime}$-[1,2-ethanediylbis-(sulfanediyl-2,1-ethanediyl)] dipyridine) showed a remarkable anti-E. histolytica activity in vitro with $\mathrm{IC}_{50}$ values of $60 \mathrm{nM}$ [12]. Toledano-Magaña et al. reported a series of neutral $\mathrm{Ru}(\mathrm{II})$ complexes containing anionic $\mathrm{O}$, O-chelating ligands (acetylacetonate derivatives), and their studies suggested some of these compounds possessed reasonable activity towards A2780 cells [13]. Furthermore, Bezerra and his partners synthesized some piplartine-containing ruthenium complexes and investigated the apoptosis inducing effect in human colon carcinoma HCT116 cells and underlying mechanisms by these ruthenium complexes-induce cell death $[14,15]$. In our recent studies, we have synthesized three $\mathrm{O}$, O-chelated ligand-bearing $\mathrm{Ru}(\mathrm{II})$ complexes, which are $\left[\mathrm{Ru}(\mathrm{bpy})_{2}(\mathrm{SA})\right]$ $(\mathrm{SA}=$ salicylate $),\left[\mathrm{Ru}(\mathrm{phen})_{2}(\mathrm{SA})\right]$ and $\left[\mathrm{Ru}(\mathrm{dmb})_{2}(\mathrm{SA})\right]$, and found that these complexes induced apoptosis in A549 cells by targeting TrxR [16].

Notably, salicylic acid (SA) or o-hydroxybenzoic acid, a precursor of aspirin (AS), has been applied as a nonsteroidal anti-inflammatory drug (NSAID) [17]. Salicylate ligand has two hard and strong alkaline donor centers, which can promote chelation or metal bridging of medium to large cations [18]. As multifunctional ligands, SA and AS are attracting ever more attention for the treatment of cancer. For instance, the research of $\mathrm{Wu}$ et al. demonstrated that conjugation of SA or AS to the Ir(III) moiety could improve the cellular uptake efficacies of the $\operatorname{Ir}(\mathrm{III})$ complexes and achieve a high synergistic effect [19]. Liu and Dhar et al. reported that a novel $\mathrm{Pt}(\mathrm{IV})$ prodrug of cisplatin, asplatin, with the ligation of aspirin $\left(c, c, t-\left[\mathrm{PtCl}_{2}\left(\mathrm{NH}_{3}\right)_{2}(\mathrm{OH})\right.\right.$ (aspirin)]), demonstrated significantly higher cytotoxicity than cisplatin towards tumor cells and nearly completely overcame the drug resistance of cisplatin-resistant cells [20-22]. Recently, Kowalski reported a new rhenium compound with AS as the ligand, $f a c-\left[\operatorname{Re}(\mathrm{CO})_{3}(\right.$ phen $)($ aspirin $\left.)\right]$, which exhibited activity against HeLa human cancer cells, and this anticancer activity could be linked to ROS production, and cell cycle disturbance followed by triggering an apoptotic pathway of cell death [23]. Similar exciting antitumor effect has also been found in other metal-based complexes of SA. For example, silver(I) [24-26] and copper(II) [18, 27] complexes with SA as the ligand exhibited strong antiproliferative activity against cancer cell lines.

For enhancing anticancer effect, we sought to develop novel $\mathrm{Ru}(\mathrm{II})$ complexes containing $\mathrm{O}$, O-chelated ligands and explored their biological functions. It is well-established that even small changes in the geometric structures of metalbased complexes could dramatically affect their biological activities, such as cyclometalated $\mathrm{Ru}(\mathrm{II})$ complexes and noncyclometalated $\mathrm{Ru}(\mathrm{II})$ complexes [28, 29]. Following this logic, we engineered two neutral $\mathrm{O}$, O-chelated $\mathrm{Ru}(\mathrm{II})$ complexes, that is, $\left[\mathrm{Ru}(\operatorname{dip})_{2}(\mathrm{SA})\right](\mathrm{dip}=4,7$-diphenyl-1,10phenanthroline, Ru-1) and $\left[\mathrm{Ru}(\mathrm{dmp})_{2}(\mathrm{SA})\right](\mathrm{dmp}=2,9-$ dimethyl-1,10-phenanthroline, Ru-2) (Figure 1). The new synthesized $\mathrm{Ru}(\mathrm{II})$ complexes have been investigated for their solution stability, hydrophobic property, cellular uptake, and anticancer activity. Furthermore, to facilitate the next clinical translation, the in vivo toxicity of complex Ru-1 was assessed using zebrafish embryo models.

\section{Materials and Methods}

2.1. Materials. Ultrapure MilliQ water was used in all experiments. DMSO, MTT, PBS, JC-1, DCFH-DA, PI, Hoechst 33342, Annexin V-FITC Apoptosis Detection Kit, QuantiPro $^{\mathrm{TM}}$ BCA Assay Kit, ECL ${ }^{\mathrm{TM}}$ Start Western Blotting Detection Reagent, and endocytosis inhibitors including $\mathrm{NaN}_{3}$, DOG, Sucrose and Nystatin were purchased from Sigma-Aldrich (St. Louis, MO, USA). A549 (human lung carcinoma), HepG2 (human hepatocellular carcinoma), MCF-7 (breast cancer), HeLa (human cervical cancer), and BEAS-2B (immortalized human bronchial epithelial cells) cells were purchased from American Type Culture Collection (ATCC, Manassas, VA). Cisplatin was purchased from Acros. Ruthenium standard solution was purchased from Aladdin Chemistry Co. (Shanghai, China). Cell Mitochondria Isolation Kit was purchased from Beyotime (Shanghai, China). Antibodies were purchased from Cell Signaling Technology Company. Comet assay reagent kit was purchased from Trevigen (Gaithersburg, MD, USA).

2.2. Apparatus. Microanalyses were carried out with a Perkin-Elmer 240Q elemental analyzer. Electrospray ionization mass spectrometry (ESI-MS) were recorded on Agilent LC-MS6430B Spectrometer. Fourier Transform infrared (FTIR) spectra were recorded on a Shimadzu Fourier Transform Infrared Spectrophotometer IRT racer-100 in the $4000-400 \mathrm{~cm}^{-1}$ region. ${ }^{1} \mathrm{H}$ NMR spectra were run on a Bruker AVANCE 400 spectrometer $(400 \mathrm{MHz})$. UV-Vis spectra were recorded on a Perkin-Elmer Lambda-850 spectrophotometer (PerkinElmer, USA). Inductively Coupled Plasma Mass Spectrometry (ICP-MS) was performed by NEXION-300X (PerkinElmer, USA). Flow cytometry was performed by an EPICS XL-MCL (BECKMAN COULTER, USA). Fluorescence microscopy observation was performed by Ti-E (Nikon, Japan). Microplate was read by Tecan Infinite M200 pro. Protein bands were visualized using ChemiDocTM XRS Imaging System (Bio-Rad, USA). Statistical analysis was performed using SPSS statistical software, version 17 (SPSS Inc., Chicago, IL).

2.3. Synthesis of Complex $\left[R u(d i p)_{2}(S A)\right](\boldsymbol{R u}-1)$. Complex Ru-1 was synthesized by reference to the procedure of complex $\left[\mathrm{Ru}(\mathrm{phen})_{2}(\mathrm{SA})\right]$ according to our previous report [16], with cis-[Ru(dip) $\left.{ }_{2} \mathrm{Cl}_{2}\right]$ in place of cis- $\left[\mathrm{Ru}(\mathrm{phen})_{2} \mathrm{Cl}_{2}\right]$. Firstly, a mixture of cis- $\left[\mathrm{Ru}(\mathrm{dip})_{2} \mathrm{Cl}_{2}\right] \cdot 2 \mathrm{H}_{2} \mathrm{O}(\mathrm{MW}=938.0$, $0.057 \mathrm{~g}, 0.10 \mathrm{mmol}$ ), o-hydroxybenzoic acid ( $\mathrm{MW}=138.12$, $0.0205 \mathrm{~g}, 0.15 \mathrm{mmol}$ ), and sodium hydroxide $(\mathrm{MW}=40.0$, 


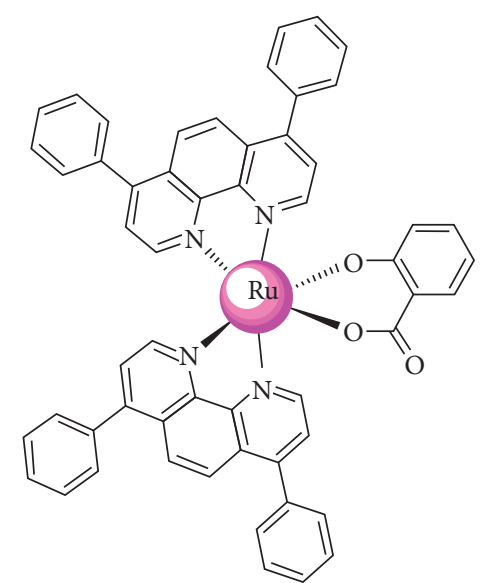

Ru-1

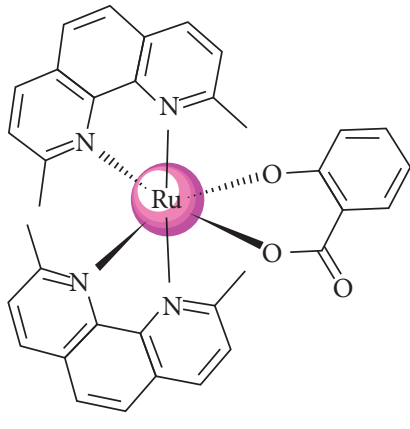

$\mathrm{Ru}-2$<smiles>O=C(O)c1ccccc1O</smiles>

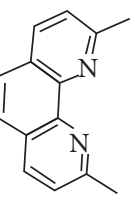

$\operatorname{dmp}$<smiles>c1ccc(-c2ccnc3c(-c4ccccc4)cccc23)cc1</smiles>

$\operatorname{dip}$

Figure 1: Structures of the $\mathrm{Ru}(\mathrm{II})$ complexes $\mathrm{Ru}(\mathrm{dip})_{2}(\mathrm{SA})(\mathbf{R u}-\mathbf{1})$ and $\mathrm{Ru}(\mathrm{dmp})_{2}(\mathrm{SA})(\mathbf{R u}-\mathbf{2})$ and the ligands of SA, dip, and dmp.

$0.012 \mathrm{~g}, 0.30 \mathrm{mmol}$ ) were dissolved in ethanol and water mixed solution $(5 \mathrm{~mL}, 5 \mathrm{~mL})$, and then, the mixture at $78^{\circ} \mathrm{C}$ for $11 \mathrm{~h}$ under the protection of argon was reflowed and a clear red solution appeared. Secondly, the solution was cooled to room temperature and concentrated by rotary evaporator at $30^{\circ} \mathrm{C}$. Finally, the precipitate was dried in vacuum and purified by chromatography over alumina (200 mesh) using ethanol/water $(1: 1, \mathrm{v} / \mathrm{v})$ as an eluent, and complex Ru-1 was obtained. Yield: $81.8 \% .{ }^{1} \mathrm{H}$ NMR $\left(400 \mathrm{MHz}, \mathrm{C}_{2} \mathrm{H}_{5} \mathrm{OH}-d_{6}\right) \delta 9.71(\mathrm{~d}, J=5.5 \mathrm{~Hz}, 1 \mathrm{H}), 9.57$ (d, $J=5.4 \mathrm{~Hz}, 1 \mathrm{H}), 8.20(\mathrm{~d}, J=8.0 \mathrm{~Hz}, 2 \mathrm{H}), 8.16-8.12(\mathrm{~m}, 2 \mathrm{H})$, 8.11-8.06 (m, 3H), $7.99(\mathrm{~d}, J=5.5 \mathrm{~Hz}, 1 \mathrm{H}), 7.94-7.87(\mathrm{~m}$, $2 \mathrm{H}), 7.75(\mathrm{~m}, 4 \mathrm{H}), 7.66(\mathrm{~m}, 4 \mathrm{H}), 7.62-7.46(\mathrm{~m}, 11 \mathrm{H}), 7.39(\mathrm{t}$, $J=5.2 \mathrm{~Hz}, 2 \mathrm{H}), 6.95(\mathrm{ddd}, J=8.6,6.8,2.0 \mathrm{~Hz}, 1 \mathrm{H}), 6.67(\mathrm{dd}$, $J=8.4 \mathrm{~Hz}, 1.3 \mathrm{~Hz}, 1 \mathrm{H}), 6.41$ (ddd, $J=8.0,6.7,1.3 \mathrm{~Hz}, 1 \mathrm{H})$ ESI-MS $(\mathrm{MeCN}): m / z=903.10\left([\mathrm{M}+\mathrm{H}]^{+}\right)$. UV-Vis $(\lambda / \mathrm{nm}$, $\left.\varepsilon / \mathrm{M}^{-1} \cdot \mathrm{cm}^{-1}\right)\left(\mathrm{CH}_{3} \mathrm{CH}_{2} \mathrm{OH}\right): 287(21275), 585(6125)$. Anal. calc. for $\mathrm{C}_{55} \mathrm{H}_{36} \mathrm{~N}_{4} \mathrm{O}_{3} \mathrm{Ru}$ : C, 73.24; H, 4.02; N, 6.21; found: C, 73.51; H, 4.03; N, 6.21. FTIR $\left(\mathrm{KBr}, \mathrm{cm}^{-1}\right): 1597\left(v_{\mathrm{as}}, \mathrm{CO}_{2}, \mathrm{~s}\right)$, $1462(\mathrm{C}-\mathrm{N}, \mathrm{s}), 1350\left(v_{\mathrm{s}}, \mathrm{CO}_{2}, \mathrm{~m}\right), 702(\mathrm{Ru}-\mathrm{O}, \mathrm{s})$.

2.4. Synthesis of Complex $\left[R u(d m p)_{2}(S A)\right] \quad(\boldsymbol{R u}$-2). Complex Ru-2 was synthesized similarly to the procedure of complex $\mathbf{R u}-\mathbf{1}$, with cis-[Ru(dmp $\left.)_{2} \mathrm{Cl}_{2}\right]$ in place of cis$\left[\mathrm{Ru}(\mathrm{dip})_{2} \mathrm{Cl}_{2}\right.$ ]. Yield: $76.5 \%$. ${ }^{1} \mathrm{H}$ NMR $(400 \mathrm{MHz}$, Pyridine$\left.d_{5}\right) \delta 8.55(\mathrm{~d}, J=7.8 \mathrm{~Hz}, 1 \mathrm{H}), 8.00(\mathrm{~d}, J=7.9 \mathrm{~Hz}, 2 \mathrm{H})$, 7.97-7.89 (m, 3H), 7.85-7.74 (m, 2H), 7.76-7.67 (m, 2H), $7.28(\mathrm{~d}, J=8.1 \mathrm{~Hz}, 2 \mathrm{H}), 7.03(\mathrm{~d}, J=8.2 \mathrm{~Hz}, 1 \mathrm{H}), 6.76(\mathrm{ddd}$, $J=8.6,6.7,2.1 \mathrm{~Hz}, 1 \mathrm{H}$ ), 6.40 (ddd, $J=7.1,6.7,1.2 \mathrm{~Hz}, 1 \mathrm{H}$ ), $6.14(\mathrm{dd}, J=8.4,1.3 \mathrm{~Hz}, 1 \mathrm{H}), 3.02(\mathrm{~s}, 3 \mathrm{H}), 2.97(\mathrm{~s}, 3 \mathrm{H}), 1.95$ $(\mathrm{s}, \quad 3 \mathrm{H}), 1.94(\mathrm{~s}, 3 \mathrm{H})$. ESI-MS (MeCN): $\mathrm{m} / z=655.09$ $\left([\mathrm{M}+\mathrm{H}]^{+}\right)$. UV-Vis $\left(\lambda / \mathrm{nm}, \varepsilon / \mathrm{M}^{-1} \cdot \mathrm{cm}^{-1}\right)\left(\mathrm{CH}_{3} \mathrm{CH}_{2} \mathrm{OH}\right)$ : 273(38250), 554(6500). Anal. calc. for $\mathrm{C}_{35} \mathrm{H}_{28} \mathrm{~N}_{4} \mathrm{O}_{3} \mathrm{Ru}$ : C, $64.31 ; \mathrm{H}, 4.32 ; \mathrm{N}, 8.57$; found: $\mathrm{C}, 64.29 ; \mathrm{H}, 4.31 ; \mathrm{N}, 8.60$. FTIR $\left(\mathrm{KBr}, \mathrm{cm}^{-1}\right): 1597\left(\mathrm{as}, \mathrm{CO}_{2}, \mathrm{~s}\right), 1462(\mathrm{C}-\mathrm{N}, \mathrm{s}), 1350\left(\mathrm{~s}, \mathrm{CO}_{2}\right.$, m), $702(\mathrm{Ru}-\mathrm{O}, \mathrm{s})$.

2.5. Cell Culture Conditions and MTT Assay. All cell lines were cultured in Roswell Park Memorial Institute 1640 culture media supplemented with $10 \%$ fetal bovine serum and incubated at $37^{\circ} \mathrm{C}$ in a $5 \% \mathrm{CO}_{2}$ incubator. The $\mathrm{IC}_{50}$ values in Table 1 were measured by MTT assay according to our previous report [16].

2.6. Cellular Uptake and Nuclear Localization. A549 cells were seeded into six-well plates $\left(5.0 \times 10^{5}\right.$ cells per well $)$ and grown overnight at $37^{\circ} \mathrm{C}$ in a $5 \% \mathrm{CO}_{2}$ incubator. The cells were incubated with the different concentrations $(5,10,15$, and $20 \mu \mathrm{M})$ of $\mathrm{Ru}(\mathrm{II})$ complexes for different time intervals $(1,3$, and $6 \mathrm{~h})$. After the incubation, the cells were harvested and washed twice with PBS. Cell Mitochondria Isolation Kit was used to extract the nuclear, mitochondrial, and cytoplasmic fractions of the A549 cells. The pellets were digested with $3 \mathrm{~mL}$ concentrated nitric acid and $1 \mathrm{~mL}$ perhydrol for $24 \mathrm{~h}$ and then diluted to $5 \mathrm{~mL}$ with ultrapure water. Finally, ICP-MS was used to determine the amount of $\mathrm{Ru}$ (II) complexes uptaken by A549 cells.

2.7. Lipophilicity Measurements. $\log P_{\mathrm{o} / \mathrm{w}}$ is the partition coefficient between octanol and water. Briefly, a suitable amount of stock solution of the $\mathrm{Ru}(\mathrm{II})$ complex in aqueous $\mathrm{NaCl}$ was added to an equal volume of octanol, and the mixture was shaken for $48 \mathrm{~h}$ at $200 \mathrm{rpm}$ at $25^{\circ} \mathrm{C}$ to allow partitioning. The aqueous layer was separated from the octanol layer after the sample was centrifuged at $3000 \mathrm{rpm}$ for $10 \mathrm{~min}$. The $\mathrm{Ru}(\mathrm{II})$ content in the aqueous layer was measured by ICP-MS. Finally, $\log P_{\mathrm{o} / \mathrm{w}}$ values were calculated according to the equation of $\log P_{\mathrm{o} / \mathrm{w}}=\log \left([\mathrm{Ru}]_{\mathrm{o}} /\right.$ $\left.[\mathrm{Ru}]_{\mathrm{w}}\right)$.

2.8. Apoptosis Assay. First, A549 cells were incubated in sixwell plates for $12 \mathrm{~h}$ and then exposed to $\mathrm{Ru}$ (II) complexes for $24 \mathrm{~h}$. After incubation, cell nuclei were stained with Hoechst $33342(5 \mu \mathrm{g} / \mathrm{mL})$ for $10 \mathrm{~min}$, washed twice with PBS, and then photographed using an inverted fluorescence microscope. Second, after incubation with different concentrations (5, 10, and $20 \mu \mathrm{M}$ ) of Ru-1 and Ru-2 for $24 \mathrm{~h}$, respectively, cells were harvested and washed twice with PBS 
TABLE 1: Cytotoxic effects of ruthenium (II) complexes on human cancer and normal cell lines ${ }^{\mathrm{a}}$.

\begin{tabular}{lcccrr}
\hline Complexes & \multicolumn{5}{c}{$\mathrm{IC}_{50}(\mu \mathrm{M})$} \\
\hline & $\mathrm{A} 549$ & HeLa & MCF-7 & HepG2 & BEAS-2B \\
$\mathrm{Ru}(\mathrm{dip})_{2} \mathrm{Cl}_{2}$ & $138.4 \pm 6.7$ & $115.6 \pm 6.8$ & $134.9 \pm 7.9$ & $108.5 \pm 5.4$ & - \\
$\mathrm{Ru}(\mathrm{dmp})_{2} \mathrm{Cl}_{2}$ & $>200$ & $>200$ & $>200$ & $169.3 \pm 6.2$ & - \\
$\mathrm{SA}$ & $>200$ & $>200$ & $>200$ & $>200$ & - \\
Ru-1 & $11.3 \pm 1.1^{\mathrm{b}}$ & $20.1 \pm 1.3^{\mathrm{b}}$ & $29.5 \pm 2.2^{\mathrm{b}}$ & $15.4 \pm 1.0$ & - \\
Ru-2 & $30.1 \pm 1.2^{\mathrm{b}}$ & $32.5 \pm 2.4^{\mathrm{b}}$ & $45.7 \pm 3.7^{\mathrm{b}}$ & $26.4 \pm 2.1$ & $54.3 \pm 3.4^{\mathrm{b}}$ \\
Cisplatin & $27.2 \pm 1.4$ & $18.3 \pm 1.2$ & $16.2 \pm 2.0$ & $30.2 \pm 2.0$ & 4.9 \\
\hline
\end{tabular}

${ }^{\mathrm{a}}$ Cells were treated with various concentrations of complexes for $48 \mathrm{~h}$. SI (selectivity index) $=\mathrm{IC}_{50}(\mathrm{BEAS}-2 \mathrm{~B}) / \mathrm{IC}_{50}(\mathrm{~A} 549){ }^{\mathrm{b}} p<0.01$ represents significant differences compared with BEAS-2B.

and then resuspended in $500 \mu \mathrm{L}$ binding buffer. The suspension was stained with $5 \mu \mathrm{L}$ Annexin V-FITC and $10 \mu \mathrm{L}$ PI at room temperature for $15 \mathrm{~min}$ and then analyzed using the flow cytometer.

2.9. MMP and ROS Determination. The mitochondrial membrane potential (MMP) of A549 cells was analyzed by using an inverted fluorescence microscope and flow cytometry. After pretreatment with different concentrations (5, 10, and $20 \mu \mathrm{M})$ of Ru-1 and Ru-2 for $12 \mathrm{~h}$, the A549 cells were trypsinized and washed twice with PBS. For microscope observation, the collected cells were incubated in complete medium containing JC-1 $(10 \mu \mathrm{g} / \mathrm{mL})$ for $30 \mathrm{~min}$ and washed with PBS twice and then imaged by an inverted fluorescence microscope (Nikon, Japan). For flow cytometry analysis, the cells were trypsinized and washed twice with PBS and then incubated in $500 \mu \mathrm{L}$ PBS containing JC-1 $(10 \mu \mathrm{g} / \mathrm{mL})$ for $30 \mathrm{~min}$ at $37^{\circ} \mathrm{C}$. The cells were analyzed by flow cytometer immediately. The intracellular ROS level of A549 cells was detected after DCFH-DA stain, as illustrated in our new publication $[16,30]$.

2.10. Comet Assay and Western Blotting Assay. Single-cell gel electrophoresis was performed to detect DNA damage, as previously described [29]. Comet assay was performed according to the manufacturer's instructions. DNA was stained with SYBR Green I (Trevigen) and imaged under an inverted fluorescence microscope.

The effects of Ru-1 on the expression levels of proteins associated with caspase, Bcl-2 family proteins, and DNA damage relative proteins were examined by western blotting assay according to our previously reported method [31]. Glyceraldehyde-3-phosphate dehydrogenase (GAPDH) was used as an internal control. The protein concentrations were determined by BCA Protein Assay Kit.

2.11. In Vivo Toxicity Assay. The in vivo toxicity of complex Ru-1 was assessed on developing zebrafish embryos. Zebrafish embryos were provided by the Zebrafish Platform of Affiliated hospital of Guangdong Medical University. Zebrafish embryos were incubated in 12-well plates with $2 \mathrm{~mL}$ solutions containing various doses of complex Ru-1 (0, $12.5,25,50,100$, and $200 \mu \mathrm{M})$ in water. An inverted microscope was used to observe the hatching and growth of the zebrafish embryos with and without Ru-1 every $24 \mathrm{~h}$. The ethical protocols used for the in vivo zebrafish embryo study were performed in line with the ethics regulations of Guangdong Medical University.

\section{Results and Discussion}

3.1. Synthesis, Characterization, and Solution Stability. Complexes Ru-1 and $\mathbf{R u}-\mathbf{2}$ were synthesized by the reaction of cis- $\left[\mathrm{Ru}(\mathrm{N}-\mathrm{N})_{2} \mathrm{Cl}_{2}\right](\mathrm{N}-\mathrm{N}=\mathrm{dip}, \mathrm{dmp})$ and salicylic acid in the presence of sodium hydroxide. The crude product was purified by chromatography over alumina. The obtained compounds were analyzed by elemental analysis, ESI-MS, ${ }^{1} \mathrm{H}$ NMR, FTIR, and UV-Vis absorption spectroscopy, and the results were shown in Figures S1-S7 in Supplementary Materials. The stability of Ru-1 and Ru-2 in water and $\mathrm{CH}_{3} \mathrm{CN}$ solution at $298 \mathrm{~K}$ was analyzed by UV-Vis absorption spectroscopy (Figures S3-S5). As demonstrated in Figures S4 and S5, there is no significant change in the UVVis absorption spectra of Ru-1 and Ru-2 at 298 K over 24 h, indicating that $\mathbf{R u}-\mathbf{1}$ and $\mathbf{R u}-\mathbf{2}$ are sufficiently stable for the majority of clinical applications. In the UV-visible spectral regions, both complexes consist of two well-resolved absorption bands. In the visible region, these two complexes present a strong MLCT transition at 500-600 $\mathrm{nm}$ attributed to the overlap $\operatorname{Ru}(\mathrm{d} \pi)$-dip or $\operatorname{dmp}\left(\pi^{*}\right)$ and $\operatorname{Ru}(\mathrm{d} \pi)$-SA $\left(\pi^{*}\right)$. The intense band occurring between $250 \mathrm{~nm}$ and $300 \mathrm{~nm}$ is attributed to an intra-ligand (IL) $\pi-\pi^{*}$ transition by comparing with the spectra of other $\mathrm{Ru}(\mathrm{II})$-polypyridyl complexes [32-34].

The obtained FTIR spectra of Ru-1 and $\mathbf{R u}-\mathbf{2}$ in $\mathrm{KBr}$ pellets are shown in Figures S6 and S7. In the FTIR spectrum of Ru-1 and Ru-2, the absorptions due to the stretching vibrations of the carboxylato unit have been recognized at 1597 and $1350 \mathrm{~cm}^{-1}[35,36]$. The band at $702 \mathrm{~cm}^{-1}$ is attributed to the $\mathrm{Ru}-\mathrm{O}$ stretch of Ru-1. Additionally, the appearance of the peak at $559 \mathrm{~cm}^{-1}$ corresponding to the $\mathrm{Ru}-\mathrm{O}$ stretch of $\mathbf{R u}-\mathbf{2}$ is consistent with $\mathrm{Ru}(\mathrm{II})$ coordination [37]. The bands at ca. $1462 \mathrm{~cm}^{-1}$ and $1465 \mathrm{~cm}^{-1}$ are the stretching vibrations of the $\mathrm{C}-\mathrm{N}$ group of the ligand dip of Ru-1 and dmp of Ru-2, separately [38, 39]. In addition, peak observed at $1365 \mathrm{~cm}^{-1}$ is attributed to the methyl of dmp of Ru-2 [38], which distinguished the IR spectrum of $\mathbf{R u - 2}$ from that of Ru-1.

Investigating the hydrolysis in the presence of biorelevant molecules is very important to assess the chemical 
stability and biological activities of these title complexes. Hence, the stability of complexes Ru-1 and Ru-2 towards bovine serum albumin (BSA) and glutathione (GSH) was also determined. As shown in Figures S8 and S9, after $12 \mathrm{~h}$ of incubation with excessive GSH or BSA, respectively, there was no significant change observed in the characteristic absorption of Ru-1 and Ru-2, which suggested that Ru-1 and $\mathbf{R u}-\mathbf{2}$ are quite stable in PBS buffer. Also, it implied that Ru-1 and Ru-2 were inactive towards GSH and BSA.

3.2. In Vitro Cytotoxicity Assay. To evaluate the in vitro anticancer activities of Ru-1 and Ru-2, the ligand $S A$ and two synthetic precursors cis- $\left[\mathrm{Ru}(\mathrm{dip})_{2} \mathrm{Cl}_{2}\right]$ and cis- $\left[\mathrm{Ru}(\mathrm{dmp})_{2} \mathrm{Cl}_{2}\right]$ were incubated with four cancer cell lines, A549, HepG2, MCF-7, HeLa, and one normal cell line BEAS-2B, at various concentrations for $48 \mathrm{~h}$. The cell viability was obtained by the MTT assay. The measured $\mathrm{IC}_{50}$ values were listed in Table 1. As shown, while the ligand $\mathrm{SA}, c i s-\left[\mathrm{Ru}(\mathrm{dip})_{2} \mathrm{Cl}_{2}\right]$ and cis$\left[\mathrm{Ru}(\mathrm{dmp})_{2} \mathrm{Cl}_{2}\right]$ displayed no/low cytotoxicity, $\mathbf{R u} \mathbf{- 1}$ and $\mathbf{R u}-\mathbf{2}$ recorded anticancer effect in all of the tested cell lines, suggesting that the coordination of polypyridine-Ru(II) center with SA is a crucial factor for the observed cytotoxic activities. It should be noted that although Ru-1 $\left(\mathrm{IC}_{50}=54.3 \pm 3.4 \mu \mathrm{M}\right)$ and Ru-2 $\left(\mathrm{IC}_{50}=48.1 \pm 3.7 \mu \mathrm{M}\right)$ show comparable low cytotoxicity towards normal BEAS-2B cells, Ru-1 displays higher anticancer activity than Ru-2, especially for A549 cell line. Hence, Ru-1 displays better selectivity between cancer cells and normal cells, indicating that it has a preferable therapeutic profile against cancer, especially lung cancer cells. This is further supported by the selectivity index (SI) assay (Table 1). Compared with Ru-2 (1.6) and cisplatin (0.8), Ru-1 (4.9) demonstrates significantly higher safety profile.

3.3. Cellular Uptake and Localization. The lipophilicity of a drug plays a vital role in its cytotoxicity [29, 40-42]. According to our studies, the cellular uptake and cytotoxicity of a ruthenium complex is positively correlated with its lipophilicity $[29,30] . \log P_{\mathrm{o} / \mathrm{w}}$ values were used to estimate the lipophilicity quantitatively. As illustrated in Figure 2(a), complex Ru-1 $\left(\log P_{\mathrm{o} / \mathrm{w}}=1.4 \pm 0.1\right)$ shows higher $\log P_{\mathrm{o} / \mathrm{w}}$ value than that of Ru-2 $\left(\log P_{\mathrm{o} / \mathrm{w}}=0.9 \pm 0.02\right)$, suggesting Ru-1 has higher lipophilicity. The above result is in line with the report that there is a positive correlation between hydrophobicity and cytotoxicity for metal-based anticancer agents [42-44].

It is generally acknowledged that the cellular uptake feature of transition metal-based compounds is an essential factor for their biological activities [45-47]. As repeatedly reported by previous ruthenium complex-related studies, the more cellular uptake results in higher cytotoxicity $[29,30,48]$. The cellular ruthenium concentration was determined by using ICP-MS after 1, 3, and $6 \mathrm{~h}$ of exposure to $5,10,15$, and $20 \mu \mathrm{M} \mathrm{Ru}$ (II) complexes (Figure 2), respectively, and the results were reported as ng of ruthenium per $10^{6}$ cell number. As expected, Ru-1 exhibits higher cellular uptake than that of Ru-2 during all the tested time points and drug concentrations (Figure 2(b) and Table S1). In a short time $(1 \mathrm{~h})$, the uptake levels were relatively low for
Ru-1 (120.3 $\pm 9.5 \mathrm{ng})$ and Ru-2 (85.4 $\pm 9.3 \mathrm{ng})$ at low drug concentration $(5 \mu \mathrm{M})$. With the extension of time and increase of concentration, the uptake levels for both Ru-1 and Ru-2 increased. The maximum cellular uptake was reached after $6 \mathrm{~h}$ of exposure to Ru-1 (432.5 $\pm 12.4 \mathrm{ng})$ and $\mathbf{R u}-\mathbf{2}$ $(235.2 \pm 16.6 \mathrm{ng})$ at the concentration of $20 \mu \mathrm{M}$, and $\mathbf{R u}-\mathbf{1}$ has a 1.8-fold better cell entry than Ru-2. The subcellular distribution of Ru-1 in A549 cells was further studied. As displayed in Figure 2(c), Ru-1 was mostly accumulated in the cell nucleus, followed by mitochondria. These results imply that Ru-1 may lead to mitochondria and nucleus damage and subsequent cancer cell apoptosis.

\subsection{Complexes $\mathbf{R u - 1}$ and $\mathbf{R u}-\mathbf{2}$ Induced A549 Cell Apoptosis.} Apoptosis, an active form of cell death, plays a vital role in cell development and survival by clearing away damaged or unwanted cells [49]. Apoptosis is an approach by which many chemical agents exert anti-cancer effect $[38,50]$. Based on the apparent proliferation inhibition of Ru-1 and Ru-2 on A549 cells, their impact on apoptosis induction was further studied via Hoechst 33342 staining technique. As presented in Figure 3(a), after treatment with both Ru-1 and Ru-2, apoptotic features including chromatin condensation, nuclear fragmentation, and plasma membrane blebbing were observed. Also, at the same concentration, complex Ru-1 induced more severe apoptosis than Ru-2 in the tested cells. To further ascertain the apoptosis induced by these $\mathrm{Ru}(\mathrm{II})$ complexes, flow cytometric analysis was carried out. As shown in Figure 3(b), both Ru-1 and Ru-2 significantly induced apoptosis in A549 cells in a concentration-dependent manner. After treatment with Ru-1 and Ru-2 at 5, 10, and $20 \mu \mathrm{M}$ for $24 \mathrm{~h}$, respectively, the percentages of late apoptotic/necrotic cells increased from $7.13 \%(5 \mu \mathrm{M})$ to $20.78 \%(20 \mu \mathrm{M})$ for Ru-1 and from $0.00 \%(5 \mu \mathrm{M})$ to $10.19 \%(20 \mu \mathrm{M})$ for $\mathbf{R u}-\mathbf{2}$, and the percentages of early apoptotic A549 cells were $14.71 \%(5 \mu \mathrm{M}), 16.27 \%(10 \mu \mathrm{M})$, and $21.57 \%(20 \mu \mathrm{M})$ for Ru-1 and $2.79 \%(5 \mu \mathrm{M}), 15.83 \%$ $(10 \mu \mathrm{M})$, and $15.47 \%(20 \mu \mathrm{M})$ for $\mathbf{R u}-2$, respectively.

When apoptosis occurred, the expression of apoptosisrelated proteins might change. So, the effect of Ru-1 on key apoptosis protein caspase-3/8/9 and poly (ADP-ribose) polymerase (PARP) were analyzed by western blotting (Figure 3(c)). As demonstrated in Figure 3(c), after treatment with Ru-1 for 24 h, the expression of cleaved-PARP, cleaved caspase-3/8/9 increased, and the expression of total caspase-3/8 decreased in a concentration-dependent manner, which illustrated that both intrinsic and extrinsic apoptotic pathways were involved in Ru-1-induced apoptosis of A549 cells. In conclusion, complexes Ru-1 and Ru-2 induced apoptosis in A549 cells probably through caspasedependent extrinsic and intrinsic pathway.

\subsection{Complexes $\mathbf{R} \boldsymbol{u}-\mathbf{1}$ and $\mathbf{R u}-\mathbf{2}$ Induced the Decrease of MMP.} Mitochondrion, which controls the energy production in most eukaryotic cells, is one of the major cell signaling center and plays a vital role in various cellular activities [51,52]. Mitochondrial dysfunction, such as the decline of 

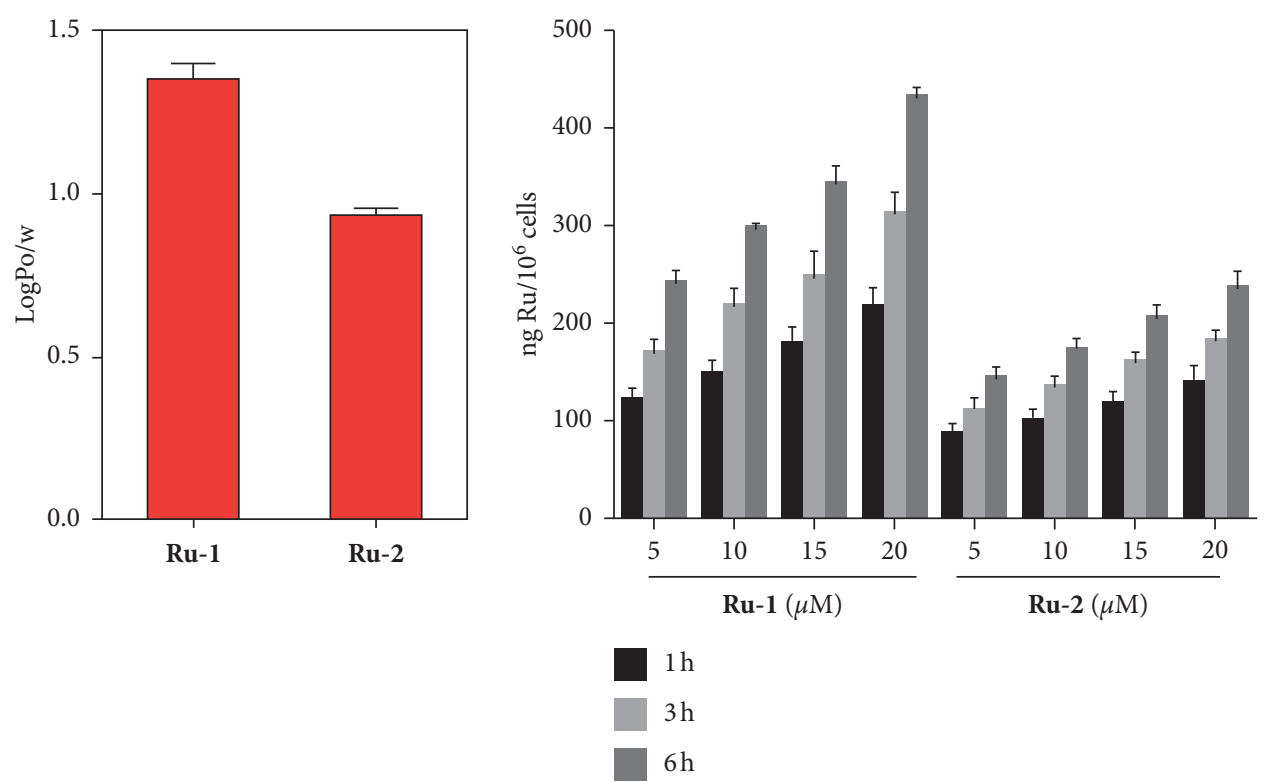

(a)

(b)

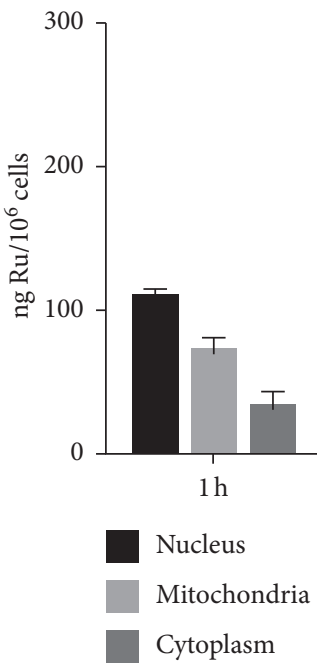

(c)

Figure 2: (a) The $\log \mathrm{P}_{\mathrm{o} / \mathrm{w}}$ values of Ru-1 and Ru-2. (b) Cellular ruthenium concentrations determined in A549 cells after 1, 3, and $6 \mathrm{~h}$ of incubation with Ru-1 and Ru-2 at 5, 10, 15, and $20 \mu \mathrm{M}$, respectively. (c) Subcellular distribution of Ru-1 in A549 cells after incubation with $20 \mu \mathrm{M}$ of Ru-1 for different times.

mitochondrial membrane potential (MMP), is an important indicator for apoptosis detection [53]. To test the effect of Ru-1 and Ru-2 on MMP, fluorescent dye JC-1-based MMP evaluation was employed. As Figure 4(a) illustrated, comparing with the untreated cells, after incubation with 5,10 , and $20 \mu \mathrm{M}$ of $\mathbf{R u}-\mathbf{1}$ or $\mathbf{R u}-\mathbf{2}$ for $12 \mathrm{~h}$, the A549 cells presented a significant red-to-green color shift in a concentrationdependent manner, suggesting the decline of MMP. Meanwhile, flow cytometry was employed to provide further information about the quantificational changes of MMP. As shown in Figure 4(b), after incubation with 5, 10, and $20 \mu \mathrm{M}$ of $\mathbf{R u}-\mathbf{1}$ or $\mathbf{R u}-\mathbf{2}$, the percentage of green fluorescence underwent a dramatic increase from $5.1 \%$ to $70.5 \%$ for $\mathbf{R u}-\mathbf{1}$ and from $5.1 \%$ to $54.0 \%$ for $\mathbf{R u}-\mathbf{2}$, respectively. The quantification of green/red fluorescent intensity ratio by JC-1 staining after 5,10 , and $20 \mu \mathrm{M}$ of $\mathbf{R u}-\mathbf{1}$ and $\mathbf{R u}-\mathbf{2}$ treatment for $12 \mathrm{~h}$ is shown in Figure 4(c).

To investigate whether the mitochondrial pathways involved in Ru-1-induced apoptosis, western blotting was further performed. As presented in Figure 4(d), after coincubation with $\mathbf{R u}-\mathbf{1}$, while the proapoptotic protein Bax and Bad displayed increased expression, the expression levels of the antiapoptotic proteins $\mathrm{Bcl}-2$ and $\mathrm{Bcl}-\mathrm{xl}$ were both downregulated. The reduction of the ratios of $\mathrm{Bcl}-2 / \mathrm{Bax}$ and $\mathrm{Bcl}-\mathrm{xl} / \mathrm{Bad}$ results in the release of cytochrome $\mathrm{c}$ into the cytosol $[54,55]$. The apparent enhancement of cytochrome $c$ expression in cytosol can be observed in Figure 4(d). The above results confirmed that $\mathbf{R u}-\mathbf{1}$ and $\mathbf{R u}-\mathbf{2}$ could induce the reduction of MMP, and the mitochondrial pathway was involved in Ru-1-induced apoptosis in A549 cells. 


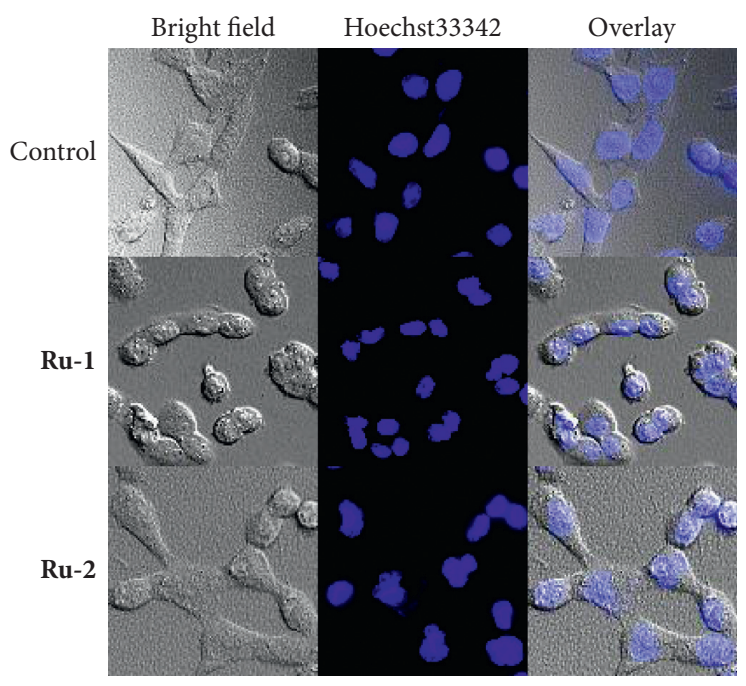

(a)

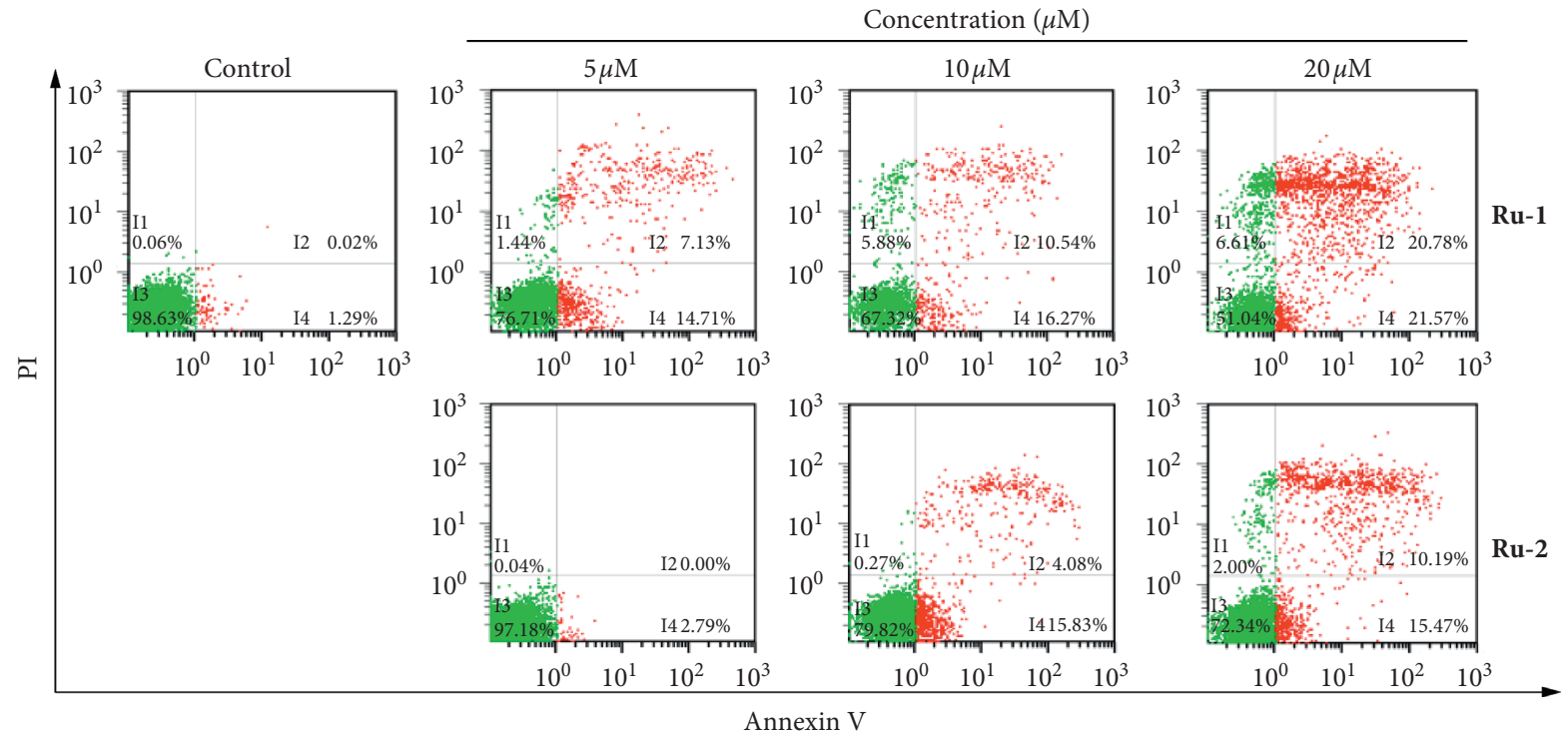

(b)

Figure 3: Continued. 


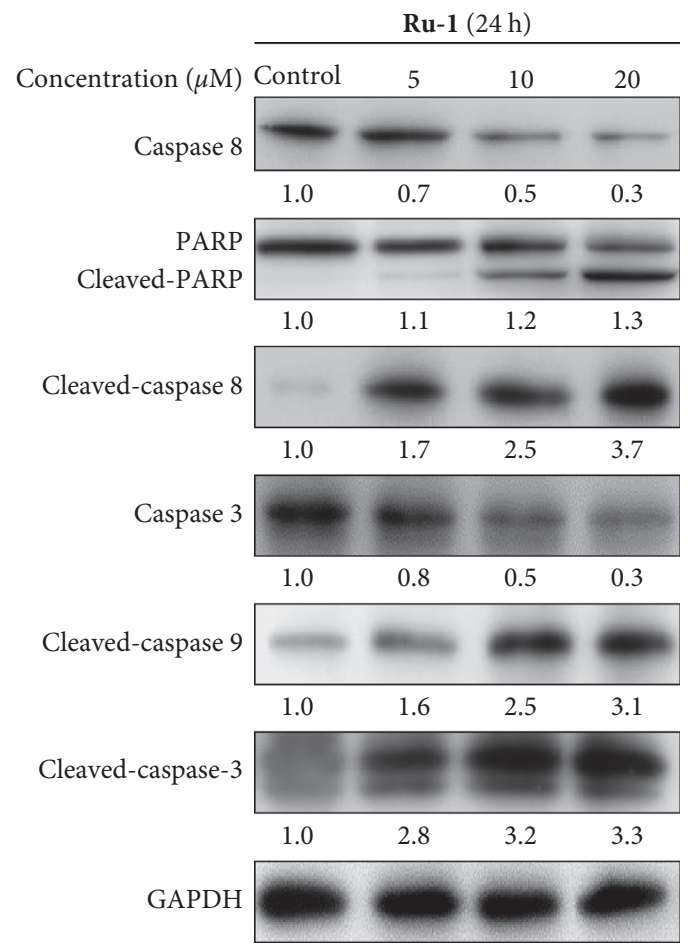

(c)

Figure 3: (a) A549 cells stained with Hoechst 33342 after treatment of Ru(II) complexes at $20 \mu \mathrm{M}$ for 24 h. (b) Apoptosis in A549 cells was detected by Annexin V/PI assay after coincubation with different concentrations of Ru(II) complexes for 24 h (I2: late apoptotic or necrotic cells, I3: living cells, and I4: early apoptotic cells). (c) The expression levels of caspase-3/8, PARP, cleaved caspase-3/8/9, and PARP were evaluated in a concentration-dependent manner with Ru-1 treatment for $24 \mathrm{~h}$.

3.6. Complexes $\mathbf{R} \boldsymbol{u}-\mathbf{1}$ and $\mathbf{R} \boldsymbol{u}-\mathbf{2}$ Activated Intracellular ROS Generation. Increasing intracellular ROS levels can trigger cell apoptosis [56]. Various $\mathrm{Ru}(\mathrm{II})$ complexes have been reported being able to enhance the intracellular ROS levels markedly $[29,30]$. To explore the roles of ROS in $\mathrm{Ru}(\mathrm{II})$ complex-induced cell apoptosis, we detected intracellular ROS levels by using an inverted fluorescence microscope and flow cytometry after staining A549 cells with DCFH-DA fluorescent dye. The results in Figure 5(a) displayed that, for both $\mathbf{R u}-\mathbf{1}$ and $\mathbf{R u}-\mathbf{2}$ groups, with the increase in the treatment concentration, a significant enhancement of DCF fluorescence signals could be observed after $12 \mathrm{~h}$ incubation. These results indicated that $\mathbf{R u}-\mathbf{1}$ and $\mathbf{R u}-\mathbf{2}$ induced overgeneration of ROS in A549 cells in a concentration-dependent manner. The quantitative result in Figure 5(b) exhibited that, at a concentration of $20 \mu \mathrm{M}$, coincubation with both Ru-1 and Ru-2 for $12 \mathrm{~h}$ could result in significant enhancement of the mean fluorescent intensity (MFI), with about 3.0- and 1.9-fold higher than the control group for $\mathbf{R u}$ $\mathbf{1}$ and $\mathbf{R u}-\mathbf{2}$, respectively.

As reported, mitochondria are both a source and target of ROS [57]. The complexes studied in this work can induce the decline of mitochondrial membrane potential (MMP) and results in mitochondrial dysfunction, which causes the damage of respiratory chain, and generates radical and nonradical species such as superoxide anion $\left(\mathrm{O}^{2-}\right)$ and hydrogen peroxide $\left(\mathrm{H}_{2} \mathrm{O}_{2}\right)$. Based on the above information, these $\mathrm{Ru}(\mathrm{II})$ complexes may stimulate the mitochondria- based ROS generation. This speculation correlates with our previous publication [31], and the $\mathrm{Ru}(\mathrm{II})$ complex-triggered ROS generation could be effectively blocked by using cyclosporine A (CsA), a confirmed mitochondrial permeability transition pore (MPTP) opening inhibitor.

\subsection{Complexes $\mathbf{R u} \mathbf{1}$ and $\mathbf{R u - 2}$ Triggered DNA Damage.} Excessive intracellular ROS can activate DNA damaged sensor proteins [58] and lead to DNA damage, an essential hallmark of cell apoptosis [59]. Indeed, the DNA damage effect has been observed in many previously developed $\mathrm{Ru}$ (II) complexes [29, 30]. To determine whether or not these complexes can induce DNA damage, the single-cell gel electrophoresis assay (comet assay) was conducted in our study. Comet assay is proved to be a rapid, simple, convenient, and straightforward method for assessing DNA damage in single cells, and the length of the comet tail represents the level of DNA damage. Also, the comet assay (DNA fragments appearance) could serve as a mark for apoptosis assessment. As shown in Figure 6(a), in the control group, there was no comet-like cell observed. After A549 cells were incubated with Ru-1 $(10 \mu \mathrm{M})$ and $\mathbf{R u}-\mathbf{2}(10 \mu \mathrm{M})$ for $12 \mathrm{~h}$, the cells presented well-formed comet tails, demonstrating the existence of severe DNA fragmentation. Increasing the concentration to $20 \mu \mathrm{M}$ recorded markedly higher levels of comet tails, showing that more DNA fragmentation has occurred. For quantitative comparison, 


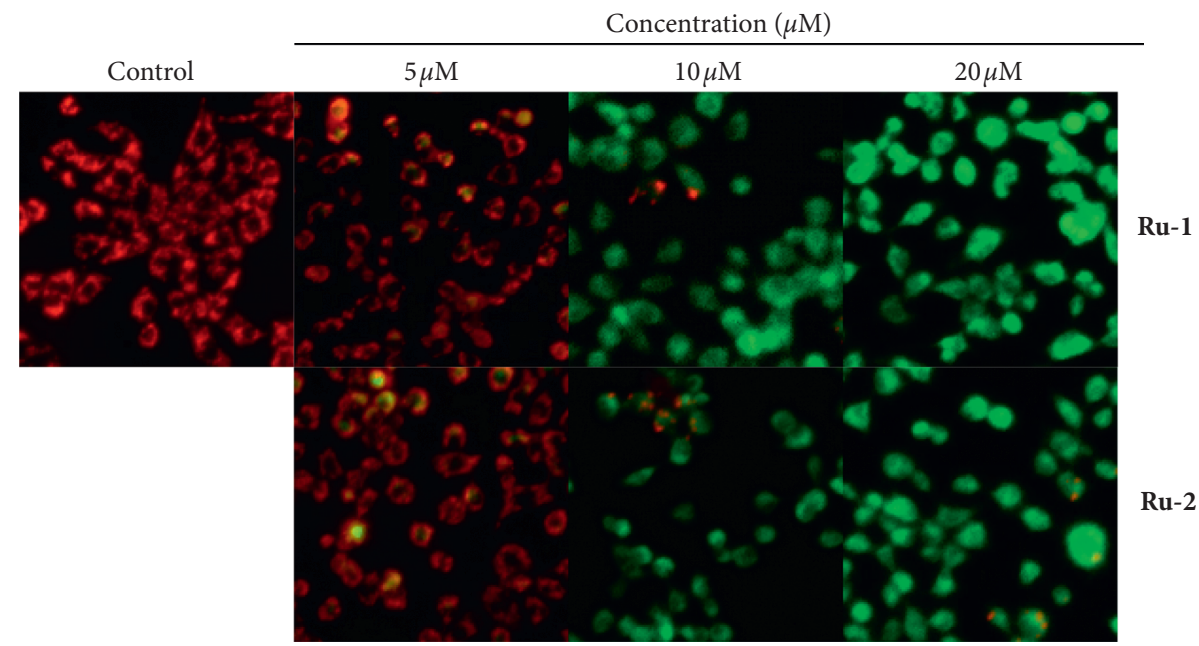

(a)

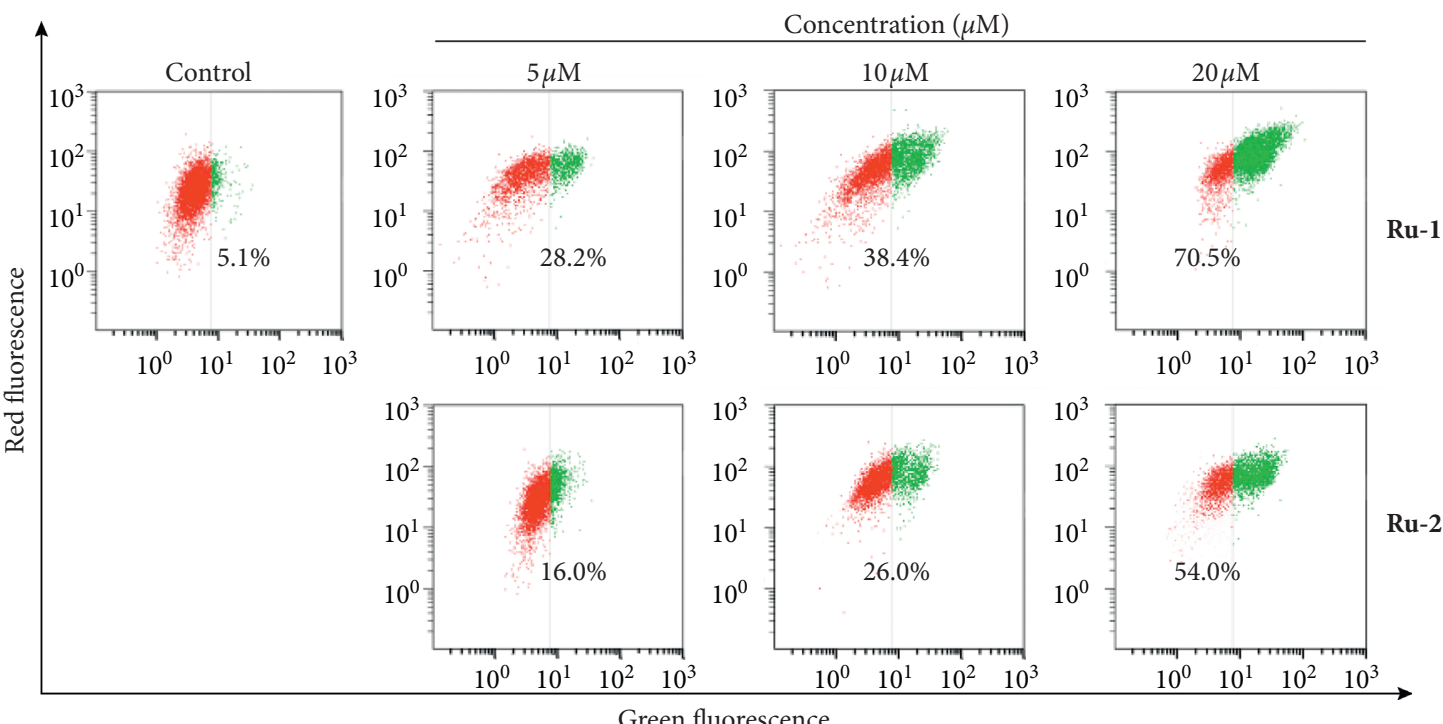

(b)
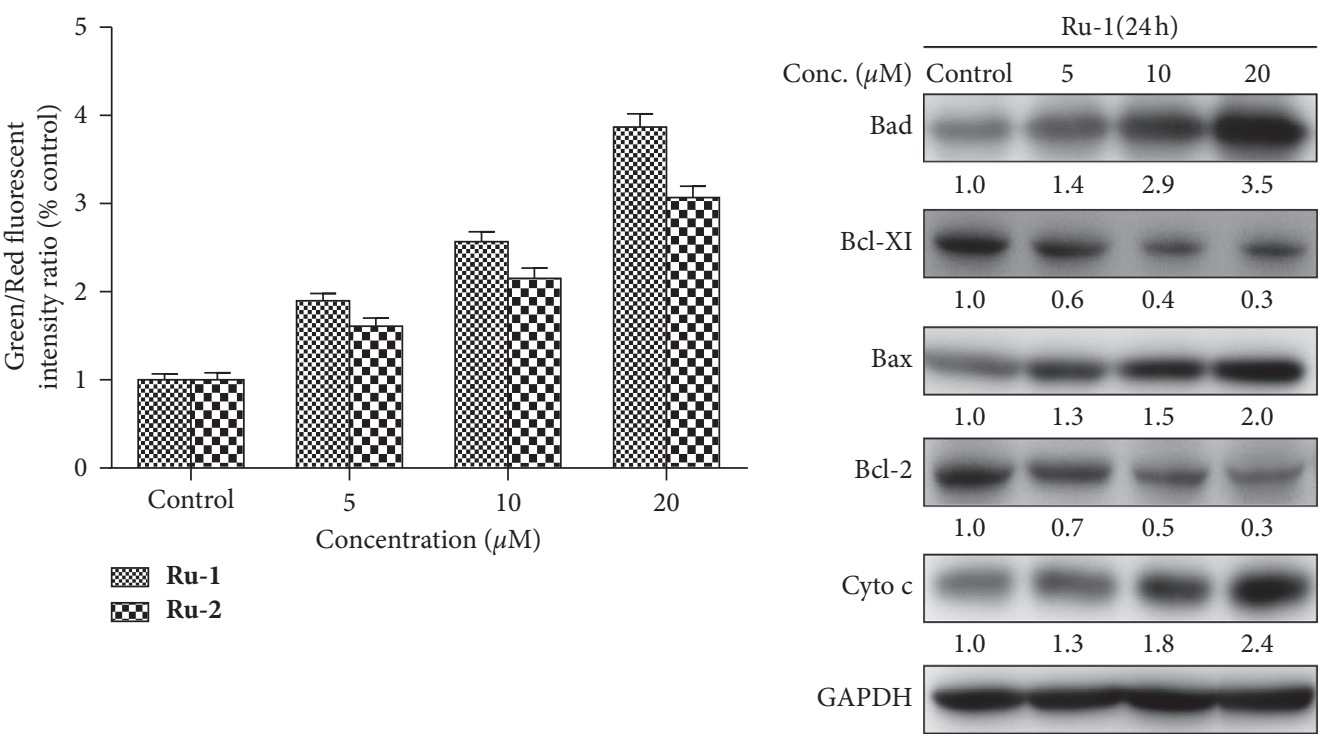

(c)

(d)

FIgURE 4: (a) Fluorescence microscopy analysis of cellular MMP level by JC-1 staining after Ru(II) complexes treatment for $12 \mathrm{~h}$. (b) Flow cytometry analysis of cellular MMP level after $\mathrm{Ru}$ (II) complexes treatment for $12 \mathrm{~h}$. (c) The quantification of green/red fluorescent intensity ratio by JC-1 staining after 5, 10, and $20 \mu \mathrm{M}$ of Ru-1 and Ru-2 treatment for $12 \mathrm{~h}$. (d) The effect of Ru-1 on the expression of Bcl-2 family proteins and cytochrome $\mathrm{c}$ in the cytosol. 


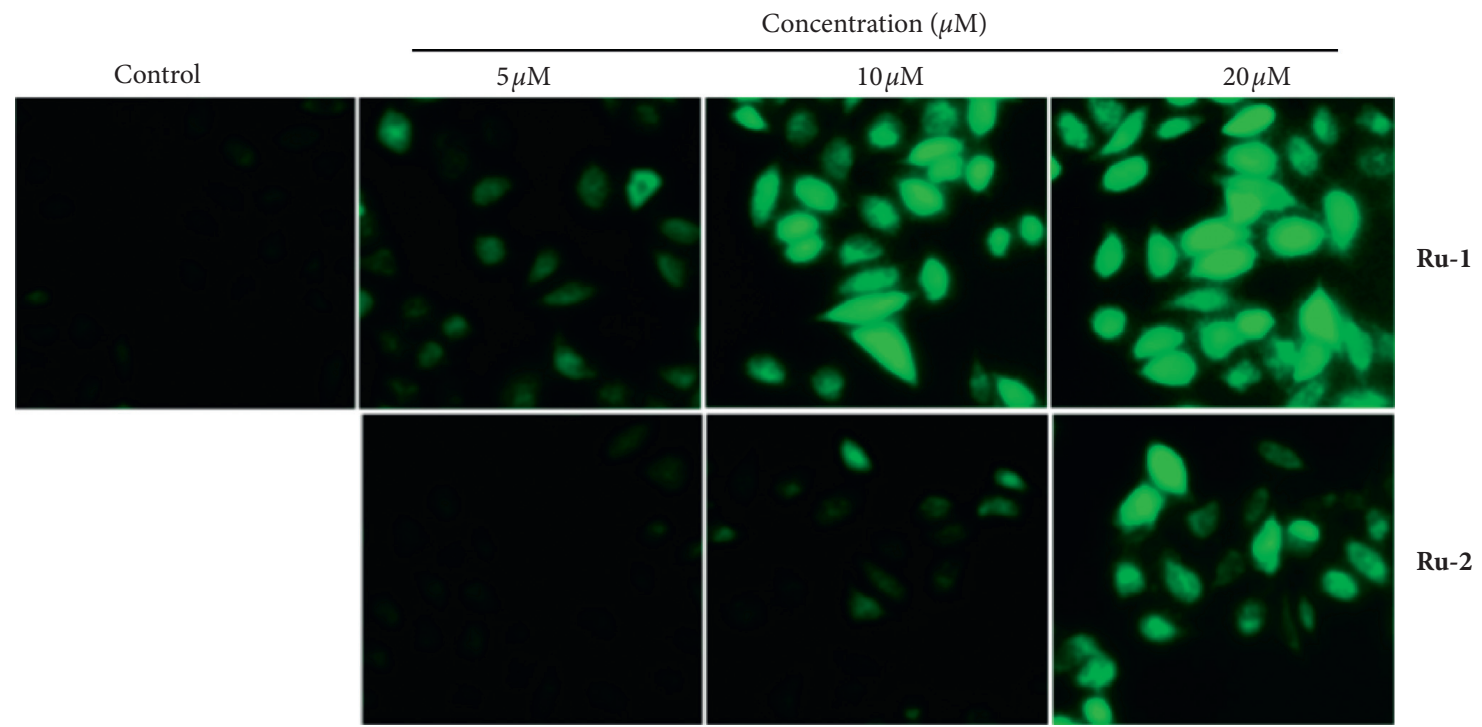

(a)
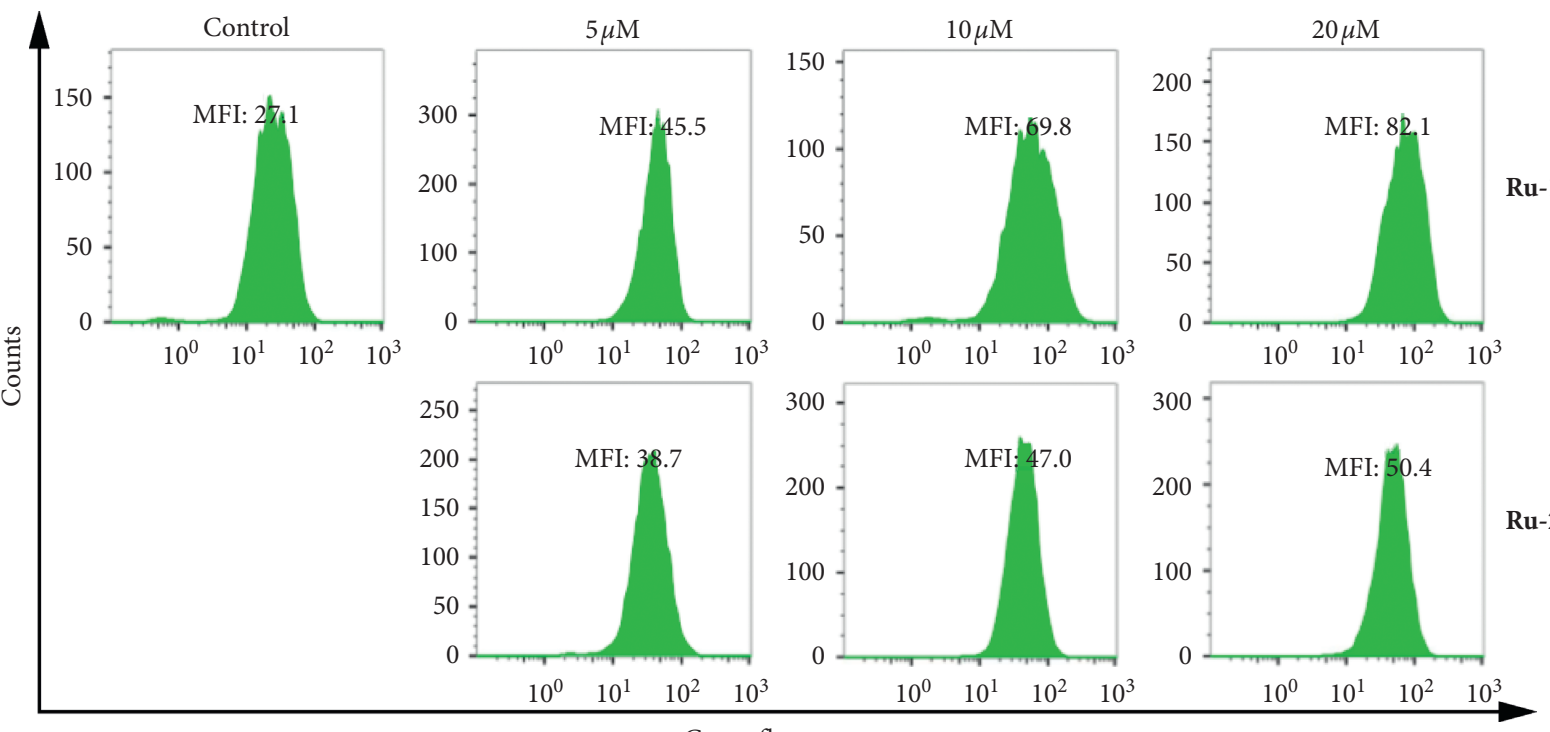

(b)

FIgURe 5: (a) The intracellular ROS level regulated by Ru-1 and Ru-2 was detected by an inverted fluorescence microscope. (b) Flow cytometry analysis of intracellular ROS level by DCFH-DA staining after different concentrations of Ru(II) complexes treatment for $12 \mathrm{~h}$.

the length of DNA tails in microscopy images was quantified by ImageJ, and the quantification of DNA tails in the comet assay was displayed in Figure 6(b). As expected, complex Ru-1 induced more DNA damage than that induced by Ru-2 based on the same external concentrations (Figure 6(b)).

In addition, Ru-1-induced DNA damage was further confirmed by analyzing common DNA damage markers via western blotting assay (Figure 6(c)), as evidenced by the upregulation of the phosphorylation levels of ATM, ATR, histone, and p53 in a concentration-dependent manner. Meanwhile, Chk1 and Chk2 were activated, accompanied by the increased phosphorylation levels of Chk1 and Chk2. The induction of p53 in response to DNA damage is synergistic with ATM/ATR, which can recruit Chk1/Chk2 and subsequently activate downstream cell cycle arrest-associated effector CDC25, causing cell apoptosis [60-62]. Therefore, these results demonstrated that $\mathbf{R u}-\mathbf{1}$ and $\mathbf{R u}-\mathbf{2}$ can trigger DNA fragmentation, that is, the apoptosis-mediated cell death.

The comet tail observed does not mean that the ruthenium complexes directly damage DNA. As reported, the excess intracellular ROS could attack DNA, resulting in DNA damage $[58,59]$. So, the observed DNA damage may result from the increased intracellular ROS levels. This has been confirmed by our previous study (the cyclometalated $\mathrm{Ru}(\mathrm{II}) \beta$-carboline complexes could induce DNA damage through ROS overproduction) [29]. In addition, according to our previous studies $[29,63,64]$, we speculate that the binding affinity of the title complexes towards DNA is not very strong because they do not have a large planar aromatic 

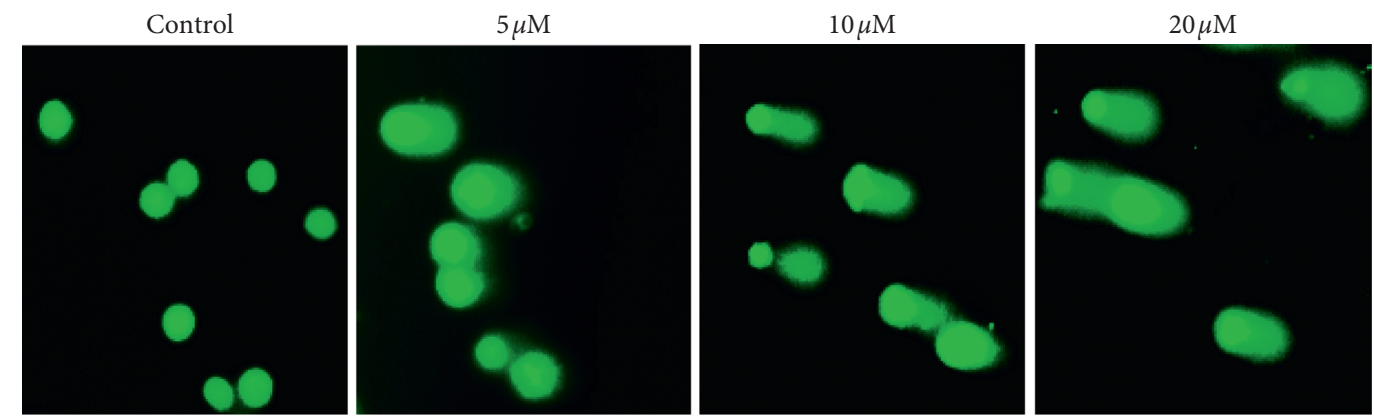

Ru-1
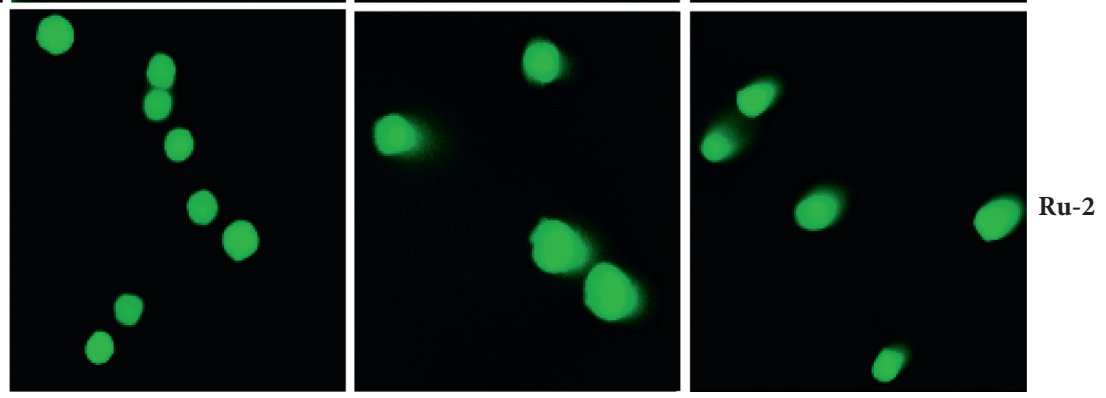

(a)
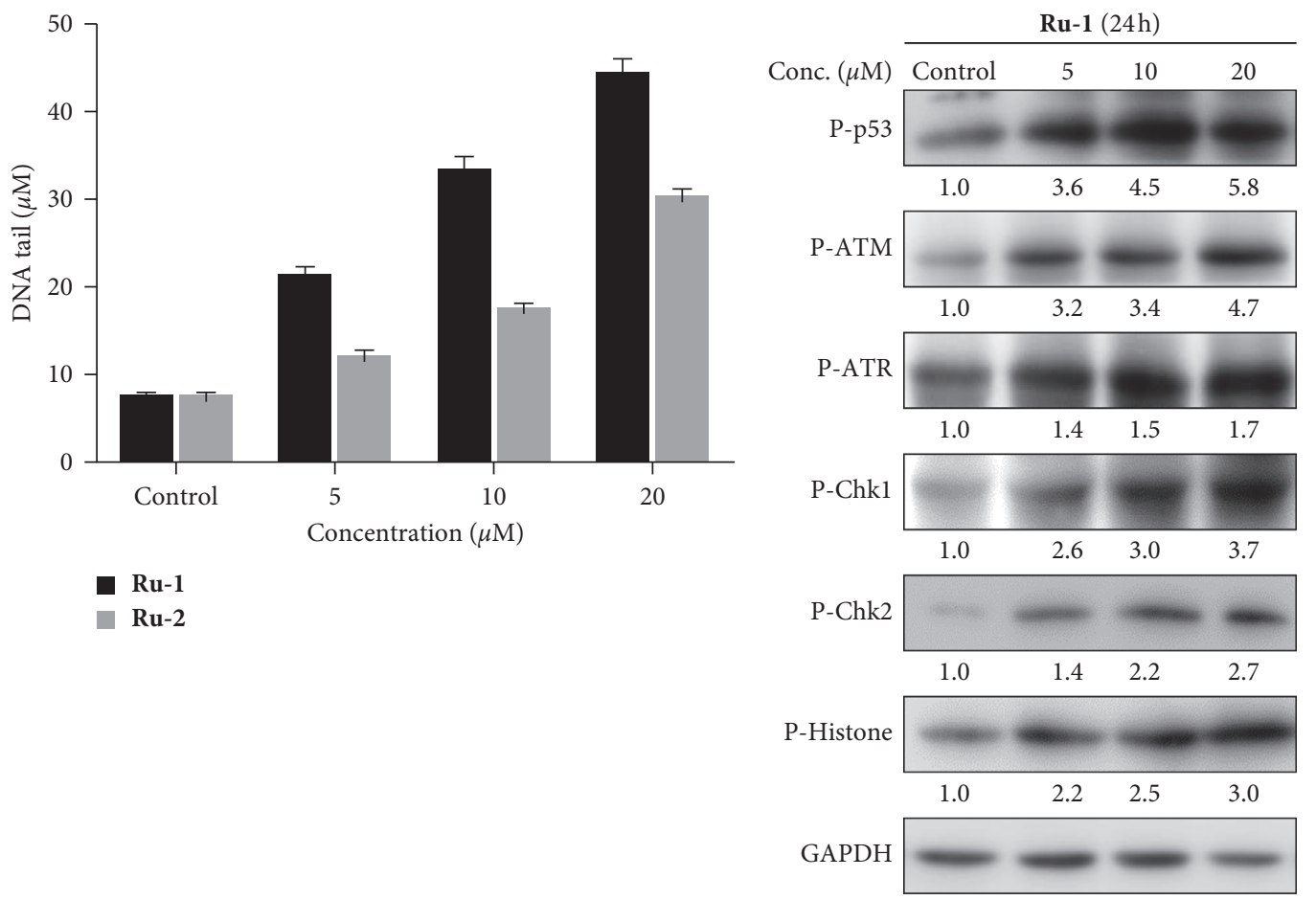

(b)

(c)

FIgURE 6: (a) DNA fragmentation triggered by Ru-1 and Ru-2 was determined by comet assay. (b) Quantification of DNA tails in the comet assay. The length of DNA tails in microscopy images was quantified by ImageJ. (c) The expression levels of phosphorylated proteins p53, ATM/ATR, Chk1/Chk2, and histone were determined by western blotting.

ligand (intercalative), such as dppz, dpq, and pip, so the interaction between them and DNA is not supposed to be the primary reason of apoptosis.

The apoptosis-mediated cell death has been commonly measured using the comet assay to detect DNA damage of cells after treatment with complexes. Comets with almost all DNA in the tail are often referred to as "hedgehog" comets and are widely assumed to represent apoptotic cells. In summary, the title complexes could induce mitochondrial dysfunction and the generation of intracellular ROS, which may indirectly lead to DNA damage.

3.8. Complex Ru-1 Showed Little Toxicity to Zebrafish Embryos. Currently, the zebrafish model is attracting unprecedented interests in biomedical research due to its high reproductive rate, short growth period, and high homology 


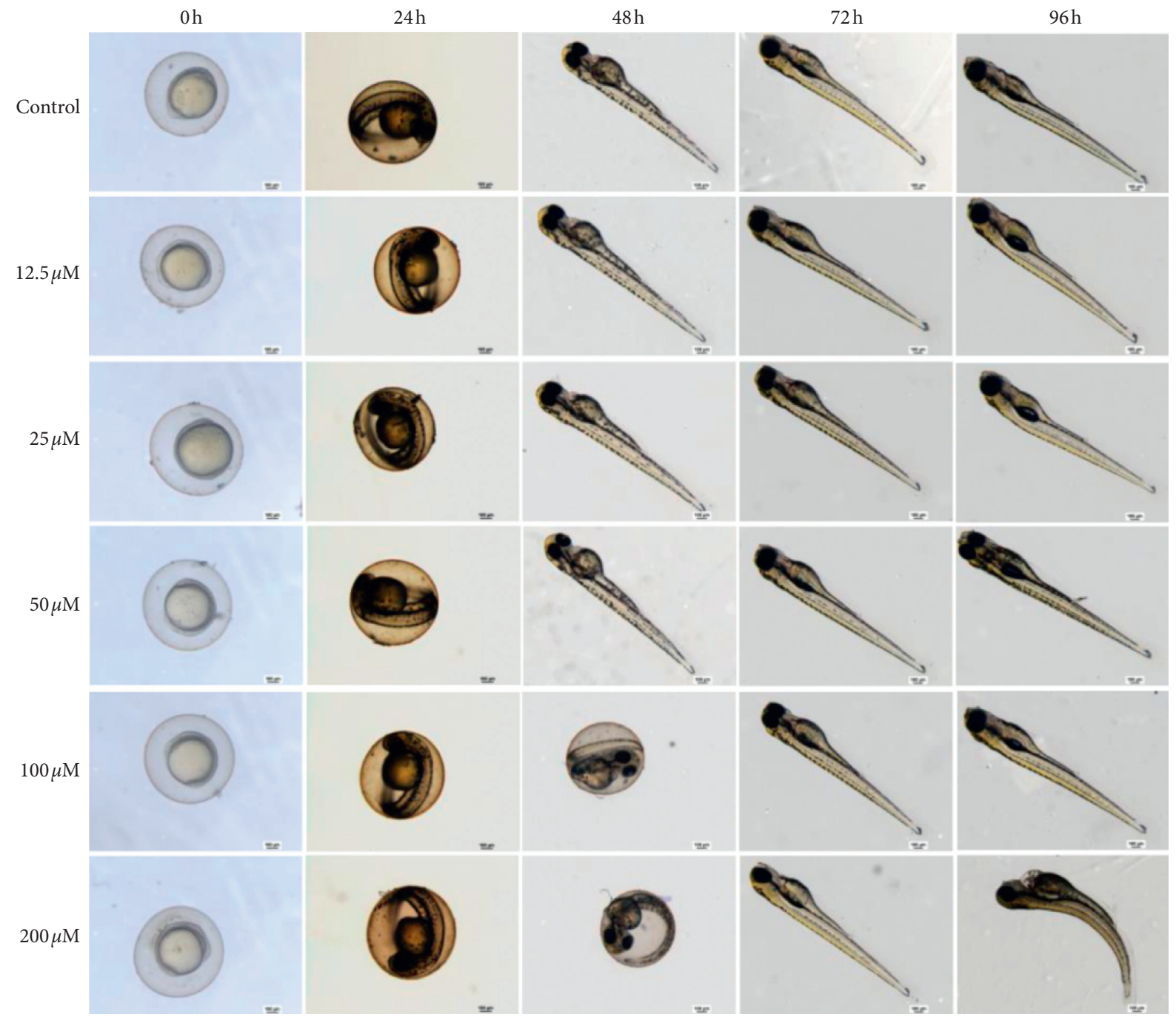

(a)

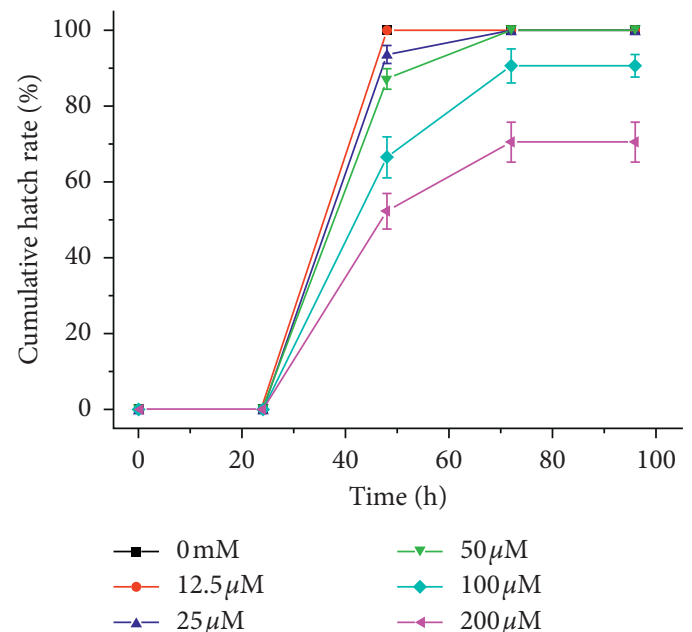

(b)

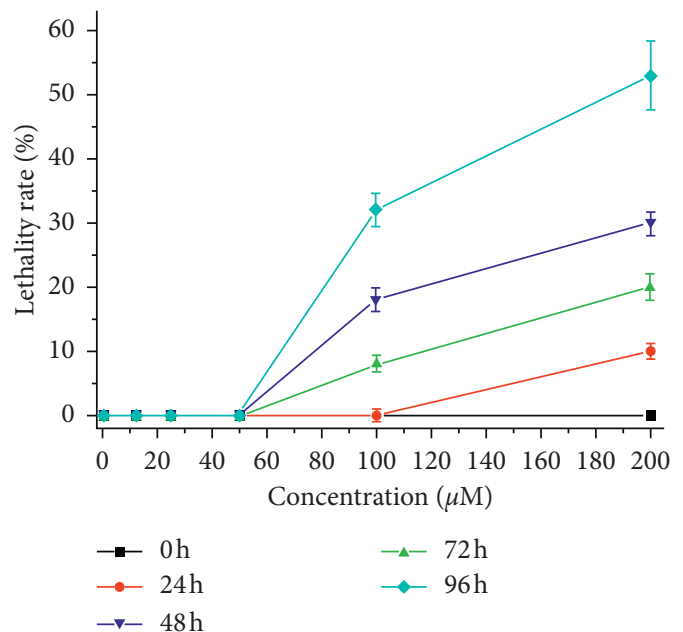

(c)

Figure 7: (a) Ecotoxicology of Ru-1 to zebrafish embryo at various concentrations for $96 \mathrm{~h}$ on a $4 \times$ objective lens in the microscope. (b) Cumulative hatching rate of zebrafish embryos in the presence/absence of Ru-1 at various concentrations every $24 \mathrm{~h}$. (c) Lethality rate of zebrafish embryos in the presence/absence of Ru-1 at different concentrations every $24 \mathrm{~h}$. 
with human DNA [65-67]. Thus, in this work, the developing zebrafish embryos were used to assess the in vivo toxicity of $\mathrm{Ru}(\mathrm{II})$ complex. As shown in Figures $7(\mathrm{~b})$ and 7(c), when treated with Ru-1 with the concentration close to $\mathrm{IC}_{50}$ value $(12.5 \mu \mathrm{M})$, the cumulative hatch rate and lethality rate display no difference compared with those of the control group. When the concentration of $\mathbf{R u}-\mathbf{1}$ was lower than $50 \mu \mathrm{M}$, all zebrafish embryos can develop into juvenile zebrafish after $96 \mathrm{~h}$. Even if the concentration of Ru-1 was up to $100 \mu \mathrm{M}$, the cumulative hatch rate was acceptable, and the lethality rate was lower than 35\% after $96 \mathrm{~h}$. Furthermore, when the concentration of Ru-1 was lower than $100 \mu \mathrm{M}$, no malformation was observed at $96 \mathrm{~h}$ (Figure 7(a)). However, when the concentration of Ru-1 was up to $200 \mu \mathrm{M}$, even after $72 \mathrm{~h}$ treatment, there were lower than $70 \%$ cumulative hatch and dramatically increased lethality rate (Figures 7(b) and 7(c)). What is more, unhealthy features such as pericardial cysts and spine curvature were notably observed at $96 \mathrm{~h}$ (Figure 7(a)). Therefore, the in vivo toxicity of Ru-1 was concentrationdependent, and no apparent side effects were found with the treatment concentrations from 12.5 to $50 \mu \mathrm{M}$. The above results indicated that complex Ru-1 showed little toxicity to zebrafish embryos. Since hypotoxicity to normal cells or organs is essential for developing anticancer agents, complex Ru-1 hold great potential to be developed as a lowtoxicity agent against lung cancer cells.

\section{Conclusions}

In summary, our study extensively evaluated the anticancer effect of two novel $\mathrm{Ru}(\mathrm{II})$ complexes containing $\mathrm{O}$, O-chelated ligands in A549 human lung cancer cells, which was mediated through inducing cell apoptosis. In addition, our results provided evidence that these complexes enhanced the level of intracellular ROS, induced a decrease of MMP, and indirectly led to DNA damage. Also, further studies showed that Ru-1 activated the caspase family proteins and PARP, downregulated the levels of the antiapoptotic protein $\mathrm{Bcl}-2$ and $\mathrm{Bcl}-\mathrm{xl}$, upregulated the levels of the proapoptotic proteins Bax and Bad, and induced the release of cytochrome $c$ in A549 cells. More importantly, Ru1 exhibited low toxicity towards both normal BEAS-2B cells in vitro and zebrafish embryos in vivo. Altogether, complex Ru-1 can induce cell apoptosis via the mitochondrial pathway, which involves mitochondrial dysfunction, ROS accumulation, and caspase-related family members' activation. This work, therefore, suggested that the title $\mathrm{Ru}(\mathrm{II})$ complexes have the potential to develop into lung cancer therapeutic agents with safety profiles.

\section{Data Availability}

The data used to support the findings of this study are given in the supplementary information file.

\section{Conflicts of Interest}

The authors declare that they have no conflicts of interest.

\section{Acknowledgments}

This research was funded by the National Natural Science Foundation of China (21701034 and 81773175), the Natural Science Foundation of Guangdong Province (2020A1515010444), Major Scientific Research Projects in Guangdong Province (Special Innovative Projects) (2017KTSCX078 and 2018KQNCX100), the Science and technology program of Guangdong Province, China (2019B090905011), the Public Service Platform of South China Sea for R\&D Marine Biomedicine Resources, Marine Biomedical Research Institute, Guangdong Medical University, the Opening Project of Guangdong Province Key Laboratory of Computational Science at the Sun Yat-sen University (no. 2018017), the Major Program of the Natural Science of Anhui University (KJ2016SD52), the China Postdoctoral Science Foundation (2018M630839), and the University Student Innovation Experiment Program. The authors would also like to thank Prof. Jingjing Zhang for providing the zebrafish platform.

\section{Supplementary Materials}

Figures S1 and S2: ESI-MS spectra of Ru-1 and Ru-2 in MeCN. Figure S3: absorption spectra of Ru-1 $(20 \mu \mathrm{M})$ and Ru-2 $(20 \mu \mathrm{M})$ in $\mathrm{CH}_{3} \mathrm{CN}$ and $\mathrm{H}_{2} \mathrm{O}$ at $298 \mathrm{~K}$ for $24 \mathrm{~h}$. Figure S4: absorption spectra of Ru-1 $(20 \mu \mathrm{M})$ and $\mathbf{R u}-\mathbf{2}(20 \mu \mathrm{M})$ in $\mathrm{CH}_{3} \mathrm{CN}$ at $298 \mathrm{~K}$ for $24 \mathrm{~h}$. Figure S5: absorption spectra of Ru-1 $(20 \mu \mathrm{M})$ and Ru-2 $(20 \mu \mathrm{M})$ in $\mathrm{H}_{2} \mathrm{O}$ at $298 \mathrm{~K}$ for $24 \mathrm{~h}$. Figures S6 and S7: FTIR spectra of Ru-1 and Ru-2 at a $1: 150$ dilution in $\mathrm{KBr}$. Figures S8 and S9: UV/vis absorption of $\mathbf{R u}-$ $\mathbf{1}$ and Ru-2 in the absence and presence of GSH or BSA. Table S1: intracellular content of Ru-1 or Ru-2 were determined by ICP-MS at different times and concentration. (Supplementary Materials)

\section{References}

[1] E. S. Antonarakis and A. Emadi, "Ruthenium-based chemotherapeutics: are they ready for prime time?" Cancer Chemotherapy and Pharmacology, vol. 66, no. 1, pp. 1-9, 2010.

[2] F. E. Poynton, S. A. Bright, S. Blasco, D. C. Williams, J. M. Kelly, and T. Gunnlaugsson, "The development of ruthenium(II) polypyridyl complexes and conjugates forin vitrocellular andin vivoapplications," Chemical Society Reviews, vol. 46, no. 24, pp. 7706-7756, 2017.

[3] L. Zeng, P. Gupta, Y. Chen et al., "The development of anticancer ruthenium(II) complexes: from single molecule compounds to nanomaterials," Chemical Society Reviews, vol. 46, no. 19, pp. 5571-5804, 2017.

[4] J. Liu, H. Lai, Z. Xiong, B. Chen, and T. Chen, "Functionalization and cancer-targeting design of ruthenium complexes for precise cancer therapy," Chemical Communications, vol. 55, no. 67, pp. 9904-9914, 2019.

[5] J. M. Rademaker-Lakhai, D. van den Bongard, D. Pluim, J. H. Beijnen, and J. H. Schellens, "A Phase I and pharmacological study with imidazolium-trans-DMSO-imidazoletetrachlororuthenate, a novel ruthenium anticancer agent," Clinical Cancer Research, vol. 10, no. 11, pp. 3717-3727, 2004. 
[6] A. Bergamo and G. Sava, "Ruthenium anticancer compounds: myths and realities of the emerging metal-based drugs," Dalton Transactions, vol. 40, no. 31, pp. 7817-7823, 2011.

[7] C. G. Hartinger, M. A. Jakupec, S. Zorbas-Seifried et al., "KP1019, a new redox-active anticancer agent-preclinical development and results of a clinical phase I study in tumor patients," Chemistry \& Biodiversity, vol. 5, no. 10, pp. 2140-2150, 2008.

[8] P. Heffeter, K. Böck, B. Atil et al., "Intracellular protein binding patterns of the anticancer ruthenium drugs KP1019 and KP1339," JBIC Journal of Biological Inorganic Chemistry, vol. 15, no. 5, pp. 737-748, 2010.

[9] D. A. Smithen, H. Yin, M. H. R. Beh et al., "Synthesis and photobiological activity of $\mathrm{Ru}(\mathrm{II})$ dyads derived from pyrrole2-carboxylate thionoesters," Inorganic Chemistry, vol. 56, no. 7, pp. 4121-4132, 2017.

[10] S. Monro, K. L. Colón, H. Yin et al., "Transition metal complexes and photodynamic therapy from a tumor-centered approach: challenges, opportunities, and highlights from the development of TLD1433," Chemical Reviews, vol. 119, no. 2, pp. 797-828, 2019.

[11] N. C. de Carvalho, S. P. Neves, R. B. Dias et al., "A novel ruthenium complex with xanthoxylin induces S-phase arrest and causes ERK1/2-mediated apoptosis in HepG2 cells through a p53-independent pathway," Cell Death \& Disease, vol. 9, no. 79, p. 79, 2018.

[12] A. Habtemariam, M. Melchart, R. Fernández et al., "Structure-Activity relationships for cytotoxic ruthenium(II) arene complexes containing N,N-, N,O-, and O,O-chelating ligands," Journal of Medicinal Chemistry, vol. 49, no. 23, pp. 6858-6868, 2006.

[13] Y. Toledano-Magaña, J. C. García-Ramos, C. Torres-Gutiérrez et al., "Water-soluble ruthenium (II) chiral heteroleptic complexes with amoebicidal in vitro and in vivo activity," Journal of Medicinal Chemistry, vol. 60, no. 3, pp. 899-912, 2017.

[14] C. O. D’Sousa Costa, J. H. Araujo Neto, I. R. S. Baliza et al., "Novel piplartine-containing ruthenium complexes: synthesis, cell growth inhibition, apoptosis induction and ROS production on HCT116 cells," Oncotarget, vol. 8, no. 61, pp. 104367-104392, 2017.

[15] I. R. S. Baliza, S. L. R. Silva, L. S. Santos et al., "Ruthenium complexes with piplartine cause apoptosis through MAPK signaling by a p53-dependent pathway in human colon carcinoma cells and inhibit tumor development in a xenograft model," Frontiers in Oncology, vol. 9, p. 582, 2019.

[16] J.-C. Chen, Y. Zhang, X.-M. Jie et al., "Ruthenium(II) salicylate complexes inducing ROS-mediated apoptosis by targeting thioredoxin reductase," Journal of Inorganic Biochemistry, vol. 193, pp. 112-123, 2019.

[17] M. A. Abdellah, S. K. Hadjikakou, N. Hadjiliadis et al., "Synthesis, characterization, and biological studies of organotin(IV) derivatives with o- or p-hydroxybenzoic acids," Bioinorganic Chemistry and Applications, vol. 2009, Article ID 542979, 12 pages, 2009.

[18] N. Palanisami, G. Prabusankar, and R. Murugavel, “A novel dimeric copper salicylate with an undissociated $\mathrm{COOH}$ group: synthesis and crystal structure of $\left[\mathrm{Cu}_{2}(\mathrm{HSal})(\mathrm{Sal})\left(2,2^{\prime} \text {-bpy }\right)_{2}\right]\left(\mathrm{ClO}_{4}\right)$, Inorganic Chemistry $^{\prime}$ Communications, vol. 9, no. 10, pp. 1002-1006, 2006.

[19] X. W. Wu, Y. Zheng, F. X. Wang et al., "Anticancer Ir III -aspirin conjugates for enhanced metabolic immuno-modulation and mitochondrial lifetime imaging," Chemistry $-A$ European Journal, vol. 25, no. 28, pp. 7012-7022, 2019.
[20] Q. Cheng, H. Shi, H. Wang, J. Wang, and Y. Liu, "Asplatin enhances drug efficacy by altering the cellular response," Metallomics, vol. 8, no. 7, pp. 672-678, 2016.

[21] Q. Cheng, H. Shi, H. Wang, Y. Min, J. Wang, and Y. Liu, "The ligation of aspirin to cisplatin demonstrates significant synergistic effects on tumor cells," Chemical Communications, vol. 50, no. 56, pp. 7427-7430, 2014.

[22] R. K. Pathak, S. Marrache, J. H. Choi, T. B. Berding, and S. Dhar, "The prodrug platin-A: simultaneous release of cisplatin and aspirin," Angewandte Chemie International Edition, vol. 53, no. 7, pp. 1963-1967, 2014.

[23] J. Skiba, A. Kowalczyk, P. Stączek et al., "Luminescent fac$\left[\operatorname{Re}(\mathrm{CO})_{3}(\right.$ phen $\left.)\right]$ carboxylato complexes with non-steroidal anti-inflammatory drugs: synthesis and mechanistic insights into the in vitro anticancer activity of fac- $\left[\operatorname{Re}(\mathrm{CO})_{3}(\right.$ phen)(aspirin)]," New Journal of Chemistry, vol. 43, no. 2, pp. 573-583, 2019.

[24] C. N. Banti, A. D. Giannoulis, N. Kourkoumelis, A. M. Owczarzak, M. Kubicki, and S. K. Hadjikakou, "Silver(I) compounds of the anti-inflammatory agents salicylic acid and p-hydroxyl-benzoic acid which modulate cell function," Journal of Inorganic Biochemistry, vol. 142, pp. 132-144, 2015.

[25] M. Poyraz, C. N. Banti, N. Kourkoumelis et al., "Synthesis, structural characterization and biological studies of novel mixed ligand $\mathrm{Ag}(\mathrm{I})$ complexes with triphenylphosphine and aspirin or salicylic acid," Inorganica Chimica Acta, vol. 375, no. 1, pp. 114-121, 2011.

[26] C. N. Banti, A. D. Giannoulis, N. Kourkoumelis et al., "Mixed ligand-silver(I) complexes with anti-inflammatory agents which can bind to lipoxygenase and calf-thymus DNA, modulating their function and inducing apoptosis," Metallomics, vol. 4, no. 6, pp. 545-560, 2012.

[27] M. O'Connor, A. Kellett, M. McCann et al., "Copper(II) complexes of salicylic acid combining superoxide dismutase mimetic properties with DNA binding and cleaving capabilities display promising chemotherapeutic potential with fast acting in vitro cytotoxicity against cisplatin sensitive and resistant cancer cell lines," Journal of Medicinal Chemistry, vol. 55, no. 5, pp. 1957-1968, 2012.

[28] H. Huang, P. Zhang, B. Yu et al., "Targeting nucleus DNA with a cyclometalated dipyridophenazineruthenium(II) complex," Journal of Medicinal Chemistry, vol. 57, no. 21, pp. 8971-8983, 2014.

[29] J. Chen, F. Peng, Y. Zhang et al., "Synthesis, characterization, cellular uptake and apoptosis-inducing properties of two highly cytotoxic cyclometalated ruthenium(II) $\beta$-carboline complexes," European Journal of Medicinal Chemistry, vol. 140, pp. 104-117, 2017.

[30] J. Chen, Y. Zhang, G. Li et al., "Cytotoxicity in vitro, cellular uptake, localization and apoptotic mechanism studies induced by ruthenium(II) complex," JBIC Journal of Biological Inorganic Chemistry, vol. 23, no. 2, pp. 261-275, 2018.

[31] L. Chen, G. Li, F. Peng et al., "The induction of autophagy against mitochondria-mediated apoptosis in lung cancer cells by a ruthenium (II) imidazole complex," Oncotarget, vol. 7, no. 49, pp. 80716-80734, 2016.

[32] H.-L. Huang, Z.-Z. Li, Z.-H. Liang, and Y.-J. Liu, "Cell cycle arrest, cytotoxicity, apoptosis, DNA-binding, photocleavage, and antioxidant activity of octahedral ruthenium(II) complexes," European Journal of Inorganic Chemistry, vol. 2011, no. 36, pp. 5538-5547, 2011.

[33] H.-J. Yu, S.-M. Huang, L.-Y. Li et al., "Synthesis, DNAbinding and photocleavage studies of ruthenium complexes 
$\left[\mathrm{Ru}(\mathrm{bpy})_{2}(\text { mitatp })\right]^{2+}$ and $\left[\mathrm{Ru}(\mathrm{bpy})_{2} \text { (nitatp) }\right]^{2+}$," Journal of Inorganic Biochemistry, vol. 103, no. 6, pp. 881-890, 2009.

[34] S. Shi, J. Liu, J. Li et al., "Electronic effect of different positions of the -NO2 group on the DNA-intercalator of chiral complexes $\left[\mathrm{Ru}(\mathrm{bpy})_{2} \mathrm{~L}\right]^{2+}(\mathrm{L}=\mathrm{o}$-npip, m-npip and p-npip)," Dalton Transactions, vol. 11, no. 11, pp. 2038-2046, 2005.

[35] L. Biancalana, G. Pampaloni, S. Zacchini, and F. Marchetti, "Synthesis, characterization and behavior in water/DMSO solution of $\mathrm{Ru}(\mathrm{II})$ arene complexes with bioactive carboxylates," Journal of Organometallic Chemistry, vol. 869, pp. 201-211, 2018.

[36] M. Hirano, H. Sato, N. Kurata, N. Komine, and S. Komiya, "Carbon-Oxygen and Carbon-Hydrogen bond cleavage reactions ofortho-substituted phenols by ruthenium(II) complexes," Organometallics, vol. 26, no. 8, pp. 2005-2016, 2007.

[37] N. C. Carvalho, S. P. Neves, R. B. Dias et al., "A novel ruthenium complex with xanthoxylin induces S-phase arrest and causes ERK1/2-mediated apoptosis in HepG2 cells through a p53-independent pathway," Cell Death and Disease, vol. 9, pp. 1-24, 2018.

[38] D. Wan, B. Tang, Y.-J. Wang et al., "Synthesis and anticancer properties of ruthenium (II) complexes as potent apoptosis inducers through mitochondrial disruption," European Journal of Medicinal Chemistry, vol. 139, pp. 180-190, 2017.

[39] F. Hayat, Zia-ur-Rehman, and M. H. Khan, "Two new heteroleptic ruthenium(II) dithiocarbamates: synthesis, characterization, DFT calculation and DNA binding," Journal of Coordination Chemistry, vol. 70, no. 2, pp. 279-295, 2017.

[40] C. A. Puckett and J. K. Barton, "Methods to explore cellular uptake of ruthenium complexes," Journal of the American Chemical Society, vol. 129, no. 1, pp. 46-47, 2007.

[41] L. Fetzer, B. Boff, M. Ali et al., "Library of second-generation cycloruthenated compounds and evaluation of their biological properties as potential anticancer drugs: passing the nanomolar barrier," Dalton Transactions, vol. 40, no. 35, pp. 8869-8878, 2011.

[42] H. Huang, P. Zhang, H. Chen, L. Ji, and H. Chao, "Comparison between polypyridyl and cyclometalated ruthenium(II) complexes: anticancer activities against 2D and 3D cancer models," Chemistry-A European Journal, vol. 21, no. 2, pp. 715-725, 2015.

[43] A. J. Millett, A. Habtemariam, I. Romero-Canelón, G. J. Clarkson, and P. J. Sadler, "Contrasting anticancer activity of half-sandwich iridium(III) complexes bearing functionally diverse 2-phenylpyridine ligands," Organometallics, vol. 34, no. 11, pp. 2683-2694, 2015.

[44] M.-G. Mendoza-Ferri, C. G. Hartinger, R. E. Eichinger et al., "Influence of the spacer length on the in vitro anticancer activity of dinuclear Ruthenium-Arene compounds," Organometallics, vol. 27, no. 11, pp. pp2405-2407, 2008.

[45] S. Nikolić, L. Rangasamy, N. Gligorijević et al., "Synthesis, characterization and biological evaluation of novel $\mathrm{Ru}(\mathrm{II})$ arene complexes containing intercalating ligands," Journal of Inorganic Biochemistry, vol. 160, pp. 156-165, 2016.

[46] V. Pierroz, T. Joshi, A. Leonidova et al., "Molecular and cellular characterization of the biological effects of ruthenium(II) complexes incorporating 2-pyridyl-2-pyrimidine4-carboxylic acid," Journal of the American Chemical Society, vol. 134, no. 150, pp. 20376-20387, 2012.

[47] R. Cao, J. Jia, X. Ma, M. Zhou, and H. Fei, "Membrane localized iridium(III) complex induces endoplasmic reticulum stress and mitochondria-mediated apoptosis in human cancer cells," Journal of Medicinal Chemistry, vol. 56, no. 9, pp. 3636-3644, 2013.
[48] Z. Zhao, Z. Luo, Q. Wu, W. Zheng, Y. Feng, and T. Chen, "Mixed-ligand ruthenium polypyridyl complexes as apoptosis inducers in cancer cells, the cellular translocation and the important role of ROS-mediated signaling," Dalton Transactions, vol. 43, no. 45, pp. 17017-17028, 2014.

[49] W. Ren, Z. Qiao, H. Wang, L. Zhu, and L. Zhang, "Flavonoids: promising anticancer agents," Medicinal Research Reviews, vol. 23, no. 4, pp. 519-534, 2003.

[50] P. Wu, S. Liu, J. Su et al., "Apoptosis triggered by isoquercitrin in bladder cancer cells by activating the AMPK-activated protein kinase pathway," Food \& Function, vol. 8, no. 10, pp. 3707-3722, 2017.

[51] H. M. McBride, M. Neuspiel, and S. Wasiak, "Mitochondria: more than just a powerhouse," Current Biology, vol. 16, no. 14, pp. R551-R560, 2006.

[52] K. Henze and W. Martin, "Essence of mitochondria," Nature, vol. 426, no. 6963, pp. 127-128, 2003.

[53] D. Yugandhar, V. L. Nayak, S. Archana, K. C. Shekar, and A. K. Srivastava, "Design, synthesis and anticancer properties of novel oxa/azaspiro[4,5]trienones as potent apoptosis inducers through mitochondrial disruption," European Journal of Medicinal Chemistry, vol. 101, pp. 348-357, 2015.

[54] J. Zhou, S. Zhang, O. Choon-Nam, and H.-M. Shen, "Critical role of pro-apoptotic Bcl-2 family members in andrographolide-induced apoptosis in human cancer cells," Biochemical Pharmacology, vol. 72, no. 2, pp. 132-144, 2006.

[55] X. Yang, L. Chen, Y. Liu et al., "Ruthenium methylimidazole complexes induced apoptosis in lung cancer A549 cells through intrinsic mitochondrial pathway," Biochimie, vol. 94, no. 2, pp. 345-353, 2012.

[56] S. H. Huang, L. W. Wu, A. C. Huang et al., "Benzyl isothiocyanate (BITC) induces $\mathrm{G}_{2} / \mathrm{M}$ phase arrest and apoptosis in human melanoma A375.S2 cells through reactive oxygen species (ROS) and both mitochondria-dependent and death receptor-mediated multiple signaling pathways," Journal of Agricultural and Food Chemistry, vol. 60, no. 2, pp. 655-675, 2012.

[57] P. D. Ray, B.-W. Huang, and Y. Tsuji, "Reactive oxygen species (ROS) homeostasis and redox regulation in cellular signaling," Cellular Signalling, vol. 24, no. 5, pp. 981-990, 2012.

[58] C. Alapetite, T. Wachter, E. Sage, and E. Moustacchi, "Use of the alkaline comet assay to detect DNA repair deficiencies in human fibroblasts exposed to UVC, UVB, UVA and gammarays," International Journal of Radiation Biology, vol. 69, no. 3, pp. 359-369, 1996.

[59] S. W. Lee, M. H. Lee, J. H. Park et al., "SUMOylation of hnRNP-K is required for p53-mediated cell-cycle arrest in response to DNA damage," The EMBO Journal, vol. 31, no. 23, pp. 4441-4452, 2012.

[60] S. Banin, L. Moyal, S. Y. Shieh et al., "Enhanced phosphorylation of p53 by ATM in response to DNA damage," Science, vol. 281, no. 5313, p. 1674, 1998.

[61] Y. Shiloh, "ATM and related protein kinases: safeguarding genome integrity," Nature Reviews Cancer, vol. 3, no. 3, pp. 155-168, 2003.

[62] B.-B. S. Zhou and S. J. Elledge, "The DNA damage response: putting checkpoints in perspective," Nature, vol. 408, no. 6811, pp. 433-439, 2000.

[63] L.-M. Chen, F. Peng, G.-D. Li et al., "The studies on the cytotoxicity in vitro, cellular uptake, cell cycle arrest and apoptosis-inducing properties of ruthenium methylimidazole complex $\left[\mathrm{Ru}(\mathrm{MeIm})_{4}(\mathrm{p} \text {-cpip) }]^{2+}\right.$," Journal of Inorganic Biochemistry, vol. 156, pp. 64-74, 2016. 
[64] L.-M. Chen, J. Liu, J.-C. Chen et al., "Synthesis, characterization, DNA-binding and spectral properties of complexes $\left[\mathrm{Ru}(\mathrm{L})_{4}(\mathrm{dppz})\right]^{2+}(\mathrm{L}=\mathrm{Im}$ and MeIm)," Journal of Inorganic Biochemistry, vol. 102, no. 2, pp. 330-341, 2008.

[65] P. Zhang, H. Huang, Y. Chen, J. Wang, L. Ji, and H. Chao, "Ruthenium(II) anthraquinone complexes as two-photon luminescent probes for cycling hypoxia imaging in vivo," Biomaterials, vol. 53, pp. 522-531, 2015.

[66] L. Sun, Y. Chen, S. Kuang et al., "Iridium(III) anthraquinone complexes as two-photon phosphorescence probes for mitochondria imaging and tracking under hypoxia," Chemistry-A European Journal, vol. 22, no. 26, pp. 8955-8965, 2016.

[67] Q. Wu, K. Zheng, S. Liao, Y. Ding, Y. Li, and W. Mei, “Arene ruthenium(II) complexes as low-toxicity inhibitor against the proliferation, migration, and invasion of MDA-MB-231 cells through binding and stabilizing c-myc G-quadruplex DNA," Organometallics, vol. 35, no. 3, pp. 317-326, 2016. 